Pengaruh Efisiensi Modal Kerja "Working Capital Turnover" Dan Debt To Equity Terhadap Profitabilitas “Return On Equity” Pada Beberapa Perusahaan Manufaktur Industri Food And Bevereges Yang Terdaftar Di Bursa Efek Indonesia (Bei) Periode 2009-2013

\author{
Deri Zul Safar
}

$\underline{\text { Dekevi446677@gmail.com }}$

\begin{abstract}
Deri Zul Safar (I1A0901010) Universitas Muhammadiyah Sukabumi. Influence Efficiency Working Capital "Working Capital Turnover" and the Debt to Equity To Profitability "Return on Equity" at the company's industry Food and Bevereges listed on the Indonesia Stock Exchange (BEI) in the period 2009-2013 (Adviser Elan Eriswanto, SE, MM and Tanti Agustiani, M. Hum).

This study aims to to assess the extent to which the influence of efficiency working capital "working capital turnover" and debt to equity to profitability "return on equity" good simultaneously and partial.

The object of this study is the working capital turnover, debt to equity and return on equity at the Food and Bevereges industry companies listed on the Indonesian Stock Exchange (BEI) in the period 2009-2013, data were analyzed on the object of the study are the financial statements of the nine industry Food and Bevereges listed on the Indonesia Stock Exchange (BEI) in the period 2009-2013.

This study uses a quantitative method with descriptive approach and associative regression analysis showed, which simultaneously Working Capital and Debt to Equity Turnover significant effect on Return on Equity of 8:06\%, while the remaining $91.93 \%$ influenced by other factors. In partial Working Capital Turnover was no significant effect on Return on Equity with $t_{\text {tcount }} 1648$ $<t_{\text {table }} 2.04523$ and Debt to equity is also partially no significant effect on Return on Equity with $t_{\text {count }}-0337<t_{\text {table }} 2.04523$, which means secera overall is that the size of the company's return on equity is less affected by Turnover Working Capital and Debt to equity. And simultaneously the size of return on equity is less affected by Turnover Working Capital and Debt to equity with a value of $F_{\text {count }} 1,447<F_{\text {tabel }} 3.284918$.
\end{abstract}

Key Word: Working Capital Turnover, Debt To Equity, Return on Equity

1 Latar Belakang Penelitian
Pada saat ini persaingan perekonomian di Indonesia semakin ketat, perusahaan 
harus mampu mengatasi dan menghadapi segala situasi dan kondisi yang akan terjadi agar mampu memenangkan persaingan usaha, dalam mencapai tujuan perusahaan yaitu memperoleh keuntungan yang diharapkan. Untuk memanfaatkan peluang, setiap perusahaan wajib memanfaatkan setiap sumber daya yang dimiliki secara optimal untuk menghasilkan suatu keunggulan yang dimiliki perusahaan. Dengan berbagai keunggulan itu, perusahaan diharapkan akan mampu mempertahankan keberadaannya di tengah persaingan yang makin ketat.

Sebuah perusahaan baik perusahaan jasa, perusahaan dagang, maupun perusahaan manufaktur dalam menjalankan usahanya tidak dapat terlepas dari modal kerja, karena dengan adanya modal kerja tersebut maka perusahaan akan mendapatkan laba atau rugi dan aktivitas perusahaan dapat dijalankan. Akan tetapi adanya modal kerja yang berlebih menunjukan adanya dana yang tidak efektif dan efisien, dan hal ini akan menimbulkan kerugian bagi perusahaan karena adanya kesempatan untuk memperoleh keuntungan telah disia - siakan. Sebaliknya adanya ketidak cukupan maupun mis management dalam modal kerja merupakan sebab utama kegagalan suatu perusahaan. Modal kerja tersebut dapat diperoleh dengan dua cara, yang pertama dari modal sendiri atau modal yang berasal dari setoran pemilik dan hasil operasi perusahaan, seperti laba dan cadangan cadangan, dan sumber dana. Sedangkan yang kedua adalah modal asing atau dana yang diperoleh dari pinjaman pihak luar perusahaan atau juga disebut pinjaman atau liabilitas, seperti pinjaman dari bank atau obligasi.

Modal kerja selalu dalam keadaan operasi atau berputar dalam perusahaan, selama perusahaan yang bersangkutan dalam keadaan beroperasi. Periode perputaran modal kerja dimulai disaat dimana kas diinvestasikan dalm komponen - komponen modal kerja sampai saat dimana kembali lagi menjadi kas. Makin pendek periode tersebut, makin cepat perputarannya atau makin tinggi tingkat perputarannya. Berapa lama periode perputaran modal kerja adalah tergantung pada berapa lama periode perputaran masing - masing komponen modal kerja tersebut. Perputaran modal kerja menunjukkan hubungan antara modal kerja dengan penjualan dan menunjukkan banyaknya penjualan yang dapat diperoleh perusahaan untuk tiap modal kerja. Perputaran modal kerja yang rendah menunjukkan adanya kelebihan modal kerja yang mungkin disebabkan rendanhnya perputaran persediaan, piutang atau adanya saldo kas yang terlalu besar. Penjualan dengan modal kerja diantaranya terdapat hubungan yang erat, bila volume penjualan naik investasi persediaan dan piutang juga meningkat, ini berarti juga meningkatkan modal kerja. Untuk menguji efesiensi penggunaan modal kerja, penganalisa dapat menggunakan perputaran modal kerja (working capital turnover). menurut Kasmir (2011: 182), yang menyatakan bahwa "Perputaran modal kerja atau working capital turn over merupakan salah satu rasio untuk mengukur atau menilai keefektifan dan kefisienan modal kerja perusahaan selama periode tertentu. Pengendalian jumlah modal kerja yang tepat akan menjamin kelancaran operasi dari perusahaan secara efesien dan ekonomis, bilamana modal kerja terlalu besar, maka dana yang tertanam dalam modal kerja melebihi kebutuhan, sehingga mengakibatkan adanya dana menganggur karena dana tersebut sebenarnya dapat digunakan untuk keperluan lain dalam rangka peningkatan laba, apabila perusahaan kekurangan modal kerja untuk memperluas penjualan dan produksinya, maka besar kemungkinannya akan kehilangan pendapatan dan keuntungan.

Penambahan liabilitas lancar dalam perusahaan mengakibatkan modal kerja yang ada dalam perusahaan juga meningkat namun perusahaan harus menanggung beban yaitu beban bunga. Pada dasarnya jika perusahaan meningkatkan jumlah liabilitas sebagai sumber dananya hal tersebut dapat meningkatkan risiko keuangan. Jika perusahaan tidak dapat mengelola dana yang diperoleh dari utang secara produktif, hal tersebut dapat memberikan pengaruh yang negatif dan berdampak terhadap menurunnya laba perusahaan. Sebaliknya jika liabilitas tersebut dapat dikelola dengan baik dan digunakan secara produktif, hal tersebut dapat memberikan pengaruh yang positif dan berdampak terhadap peningkatan laba perusahaan. 
Apabila perusahaan memperoleh dana melalui utang, para pemegang saham dapat mempertahankan kendali mereka atas perusahaan tersebut dengan sakaligus membatasi investasi yang mereka berikan dan kreditor akan melihat pada ekuitas, atau dana yang diperoleh sendiri, sebagai suatu batasan keamanan, sehingga semakin tinggi proporsi dari jumlah modal yang diberikan pemegang saham, maka semakin kecil resiko yang dihadapi kreditor, jika perusahaan mendapatkan hasil dari investasi yang didanai dengan dana hasil pinjaman lebih besar daripada bunga yang dibayarkan, maka pengembalian dari modal pemilik akan diperbesar, atau diungkit.

Perusahaan yang total liabilitas lebih besar dari total asetnya, perusahaan tersebut dikatakan tidak solvabel atau perusahaan tersebut tidak mampu membayar kewajiban - kewajibannya pada saat perusahaan di likudasi. Rasio solvabilitas digunakan untuk mengukur kemampuan perusahaan memenuhi liabilitas jangka panjangnya. Menurut Irham Fahmi (2015: 62) rasio leverage adalah mengukur seberapa besar perusahaan dibiayai dengan utang. Rasio ini juga menyangkut stuktur keuangan perusahaan. Struktur keuangan adalah bagaimana perusahaan mendanai aktivitasnya. Biasanya, aktivitas perusahaan didanai dengan utang jangka pendek, utang jangka panjang, dan modal pemegang saham. Ada beberapa macam rasio solvabilitas, yaitu debt to equity ratio, debt ratio (debt to total asset ratio), long term debt to equity, dan time intersted earned. Namun, penelitian ini hanya berfokus pada debt to equity ratio. Debt to equity rastio merupakan rasio yang mengukur sejauh mana besarnya utang dapat ditutupi oleh modal sendiri. perusahaan dengan debt to equity yang rendah akan memiliki risiko kerugian yang kecil ketika keadaan ekonomi mengalami kemerosotan, namun ketika kondisi ekonomi membaik, kesempatan dalam memperoleh laba juga rendah, sebaliknya perusahaan dengan rasio debt to equity yang tinggi memang menanggung risiko kerugian yang besar pula ketika perekonomian sedang merosot, tetapi dalam keadaan baik, perusahaan ini memiliki kesempatan memperoleh laba besar. Kreditur lebih menyukai rasio utang yang rendah karena semakin rendah rasio ini, maka semakin besar perlindungan terhadap kerugian kreditur dalam peristiwa likuidasi. Di sisi lain, pemegang saham akan menginginkan debt to equity yang lebih besar karena dapat membatasi dana untuk diinvestasikan kepada perusahaan dan akan meningkatkan laba yang diharapkan.

Untuk dapat menjaga kelangsungan hidup suatu perusahaan haruslah berada dalam keadaan menguntungkan atau Profitable. Tanpa adanya keuntungan akan sangat sulit bagi perusahaan untuk menarik modal dari luar. Para kreditor, pemilik perusahaan dan terutama sekali pihak manajemen perusahaan akan berusaha meningkatkan keuntungan ini, karena disadari betul betapa pentingnya arti keuntungan bagi masa depan perusahaan. Terdapat beberapa cara pengukuran yang dapat dipergunakan untuk mengukur keuntungan perusahaan. Masing-masing pengukuran tersebut dihubungkan dengan volume penjualan, total assets dan modal sendiri. Secara keseluruhan ketiga pengukuran ini akan memungkinkan penganalisis untuk menganalisis tingkat earning dalam hubungannya dengan volume penjualan, jumlah asset dan jumlah investasi tertentu. Rasio untuk mengukur tingkat laba yaitu rasio profitabilitas, rasio profitabilitas menurut Irham Fahmi (2015: 135), mengatakan bahwa rasio profitabilitas adalah "Rasio yang mengukur efektivitas secara keseluruhan yang ditunjukan oleh besar kecilnya tingkat keuntungan yang diperoleh dalam hubungannya dengan penjualan maupun investasi". Macam macam rasio profitabilitas yang dipergunakan untuk mengukur tingkat laba tersebut yaitu Gross profit margin, Operating Profit Margin, Net Profit Margin, Return On Investment (ROI), Return On Equity (ROE). Dalam karya ilmiah ini rasio profitabilatas yang akan digunakan untuk mengukur tingkat laba yaitu Return on equity (ROE), return on equity adalah suatu rasio yang digunakan untuk mengukur besarnya tingkat pendapat yang tersedia bagi para pemilik perusahaan baik pemegang saham biasa maupun pemegang saham preferen atas modal yang mereka investasikan di dalam perusahaan. Secara umum, semakin tinggi rasio ini menunjukkan semakin tingginya pula tingkat 
penghasilan yang diperoleh para pemegang saham atau pemilik perusahaan.

Berdasarkan gambaran permasalahan di atas perusahaan dituntut untuk mendapatkan tingkat profitabilitas yang optimal dengan menggunakan modal kerja secara efisien dan sumber dana pinjaman yang tepat, maka penulis tertarik mengambil judul "Pengaruh Efisiensi Modal Kerja (Working Capital Turn Over) dan Debt to Equity terhadap Profitabilitas (Return on Equity) pada perusahaan industry Food and Bevereges yang terdaftar di Bursa Efek Indonesia (BEI) periode 2009 - 2013".

\section{Modal Kerja}

Modal kerja merupakan keseluruhan aset lancar yang dimilki perusahaan atau dapat pula dimaksudkan sebagai dana yang harus disediakan untuk membiayai kegiatan operasi sehari - hari.

Menurut Sri Dwi Ari Ambarwati (2010: 112) "Modal kerja adalah modal yang seharusnya tetap ada dalam perusahaan sehingga operasional perusahaan menjadi lebih lancar serta tujuan akhir perusahaan untuk menghasilkan laba akan tercapai. Adapun modal kerja itu dapat diperoleh dari modal sendiri ataupun dari pinjaman bank".

Menurut Houston \& Brigham (2010; 131) menyatakan bahwa "Modal Kerja adalah suatu investasi perusahaan didalam aktiva jangka pendek seperti kas, sekuritas (surat-surat berharga), Piutang Dagang dan Persediaan".

Menurut Kasmir (2011: 249) “ Modal kerja merupakan dana yang digunakan untuk membiayai kegiatan operasional perusahaan, terutama yang memiliki jangka waktu pendek."

Dari definisi di atas, menunjukan bahwa modal kerja adalah jumlah keseluruhan aktiva lancar yang dimiliki oleh perusahaan dan yang dipergunakan juga untuk operasi perusahaan tersebut.

\subsection{Jenis - Jenis Modal Kerja}

Menurut Sri Dwi Ambarwati dan Bambang riyanto (2012: 112) yang berdasarkan pendapat AW Taylor, Modal dibedakan menjadi dua, yaitu:

1. Modal kerja permanen, adalah modal kerja yang harus ada dalam perusahaan untuk memenuhi kebutuhan konsumen berupa barang jadi. Modal kerja permanen dibedakan menjadi dua, yaitu: a. Modal kerja primer, asalah modal kerja minimal yang harus dimiliki perusahaan agar dapat terus beroprasi.

b. Modal kerja normal, adalh modal kerja yang harus ada dalam perusahaan agar dapat beroprasi dalam kapasitas normal.

2. Modal kerja variabel, adalah modal kerja yang selalu berubah proporsional dengan perubahan kapasitas produksi. modal kerja ini terdiri dari:

a. Modal kerja musiman, merupakan modal kerja yang berubah sesuai perubahan musim/permintaan, misalnya permintaan besar pada waktu hari raya.

b. Modal kerja siklis, merupakan modal kerja yang berubah akibat konjungtor.

c. Modal kerja darurayt, merupakan modal kerja yang berubah sesuai dengan keadaan yang terjadi di luar kemampuan perusahaan.

\subsection{Konsep Modal Kerja}

Menurut Sri Dwi Ambarwati (2010: 114), seperti juga yang dikutip oleh Bambang Riyanto (1995) bahwa ada tiga konsep modal kerja, yaitu:

1. Modal kerja kuantitatif, modal kerja menurut konsep ini adalah keseluruhan elemen aktiva lancar, sehingga disebut modal kerja bruto karena tidak memperhatikan utang jangka pendeknya, misal: kas, piutang dan persediaan.

2. Modal kerja kualitatif, modal kerja dalam konsep ini adalah semua elemen aktiva lancar dikurangi seluruh utang jangka pendek yang harus dibayar perusahaan.

3. Modal kerja fungsional, modal kerja menurut konsep iniadalah dana yang digunakan perusahaan dalam mencapai laba. Misal: kas, pituangdagang, persediaan barang dagang, penyusutan mesin, penyusutan gedung dan bangunan. Sedangkan efek baru menjadi modal kerja jika sudah dijual.

Dalam penelitian ini peneliti menggunakan konsep modal kerja kualitatif, modal kerja dalam konsep ini adalah semua 
elemen aktiva lancar dikurangi seluruh utang jangka pendek yang harus dibayar perusahaan.

\subsection{Faktor-Faktor yang Memengaruhi Modal Kerja}

Menurut Kasmir (2011: 254) modal kerja yang dibutuhkan perusahaan harus segera terpenuhi sesuai dengan kebutuhan perusahaan. Namun, terkadang untuk memenuhi kebutuhan modal kerja seperti yang diinginkan tidaklah selalu tersedia. Hal ini disebabkan terpenuhi tidaknya kebutuhan modal kerja sangat tergantung kepada berbagai faktor yang mempengaruhinya. Ada beberapa faktor yang dapat mempengaruhi modal kerja, yaitu:

1. Jenis Perusahaan, jenis kegiatan perusahaan dalam praktiknya meliputi dua macam, yaitu: perusahaan yang bergerak dalam bidang jasa dan non jasa. Kebutuhan modal dalam perusahaan industri lebih besar jika dibandingkan dengan perusahaan jasa.

2. Syarat Kredit, syarat kredit atau penjualan yang pembayarannya dilakukan dengan cara mencicil juga sangat mempengaruhi modal kerja. Untuk meningkatkan penjualan bisa dilakukan dengan berbagai cara dan salah satunya adalah melalui penjualan secara kredit.

3. Waktu Produksi, jangka waktu atau lamanya memproduksi suatu barang. Makin lama makin waktu yang digunakan untuk memproduksi suatu barang, maka akan semakin besar modal kerja yang dibutuhkan. Demikian pula sebaliknya semakin pendek waktu yang dibutuhkan untuk memproduksi modal kerja maka semakin kecil modal kerja yang dibutuhkan.

4. Tingkat Perputaraan Persediaan, tingkat perputaran persediaan terhadap modal kerja cukup penting bagi perusahaan. Semakin kecil atau rendah tingkat perputaran, kebutuhan modal kerja semakin tinggi, demikian pula sebaliknya. Dengan demikian, dibutuhkan perputaran persediaan yang cukup tinggi agar memperkecil resiko kerugian akibat penurunan harga serta mampu menghemat biaya penyimpanan dan pemeliharaan persediaan.

\section{Analisis Rasio Keuangan}

Rasio keuangan atau financial ratio ini sangat berguna untuk melakukan analisa terhadap kondisi keuangan perusahaan. Rasio keuangan ini hanya menyederhanakan informasi yang menggambarkan hubungan antara pos tertentu dengan pos lainnya, misalnya antara utang dan modal, antara kas dan total aset, antara harga pokok produksi dengan total penjualan, dan lain - lain.

Hal tersebut ditegaskan oleh Sofyan Safri Harahap (2013: 297) menyatakan bahwa "analisis rasio keuangan adalah angka yang diperoleh dari hasil perbandingan dari satu pos laporan keuangan dengan pos lainnya yang mempunyai hubungan yang relevan dan signifikan".

Menurut Munawir (2010: 35), analisis laporan keuangan adalah analisis laporan keuangan yang terdiri dari penelaahan atau mempelajari daripada hubungan dan tendensi atau kecenderungan (trend) untuk menentukan posisi keuangan dan hasil operasi serta perkembangan perusahaan yang bersangkutan.

Berdasarkan pengertian di atas, dapat disimpulkan bahwa raso keuangan digunaka perusahaan untuk membandingkan pos satu dengan pos lainnya dimana hasil rasio tersebut merupakan ukuran yang penting bagi perusahaan karena dapat melihat kondisi keuangan perusahaan apakah dalam keadaan beresiko atau dalam keadaan aman.

\subsection{Manfaat dan Tujuan Analisis Rasio Keuangan}

Menurut Kasmir (2011: 92), secara umum dikatakan bahwa tujuan dan manfaat dari analisis laporan keuangan adalah :

1. Untuk mengetahui posisi keuangan perusahaan dalam satu periode tertentu, baik harta, kewajiban, modal, maupun hasil usaha yang telah dicapai untuk beberapa periode.

2. Untuk mengetahui kelemahan apa saja yang menjadi kekurangan perusahaan.

3. Untuk mengetahui kekuatan yang dimiliki oleh perusahaan.

4. Untuk mengetahui langkah - langkah perbaikan apa saja yang perlu dilakukan ke depan yang berkaitan dengan posisi keuangan perusahaan saat ini. 
5. Untuk melakukan penilaian kinerja manajemen ke depan apakah perlu penyegaran atau tidak karena sudah dianggap berhasil atau gagal.

6. Dapat juga digunakan sebagai pembanding dengan perusahaan sejenis tentang hasil yang mereka capai.

Menurut Irham Fahmi (2015 :108)

manfaat analisis rasio keuangan diantaranya:

1. Analisis rasio keuangan sangat bermanfaat untuk sebagai alat menilai kinerja dan prestasi perusahaan.

2. Analiss rasio keuangan sangat bermanfaat bagi pihak manajemen sebagai rujukan untuk membuat perencanaan.

3. Analisis rasio keuangan dapat dijadikan sebagai alat untuk mengevaluasi kondisi suatu perusahaan dari perpektif keuangan.

4. Analisis rasio keuangan juga bermanfaat bagi para kreditor dapat digunakan untuk memperkirakan potensi resiko yang akan dihadapi dikaitakan dengan adanya jaminan kelangsungan pembayaran bungan dan pengembalian pokok pinjaman.

5. Analisis rasio keuangan dapat dijadikan sebagi penilaian bagi pihak stakeholder organisasi.

Berdasarkan penjelasan diatas analisis rasio perusahaan merupakan langkah awal dalam analisis keuangan, karena sebagaimana fungsinya rasio keuangan dirancang dapat digunakan untuk memberi gambaran hubungan perkiraan - perkiraan laporan keuangan.

\subsection{Jenis - Jenis Rasio Keuangan}

Menurut Riyanto (2010: 330), apabila dilihat dari sumber darimana rasio ini dibuat, maka dapat digolongkan dalam 3 (tiga) golongan, yaitu:

1. Rasio neraca (Balance Sheet Ratios), yang digolongkan dalam katagori ini adalah semua data yag diambil dari atau bersumber dari neraca.

2. Rasio-rasio laporan laba-rugi (Income Statement Ratios), yang tergolong dalam katagori ini adalah semua data yang diambil dari laba-rugi.

3. Rasio-rasio antar laporan (Interstatement Ratios), yang tergolong dalam katagori ini adalah semua data yang diambil dari neraca dan laporan laba-rugi.

Menurut Riyanto (2010: 331), umumnya rasio dapat dikelompokkan dalam 4 (empat) tipe dasar, yaitu :

1. Rasio Likuiditas, adalah rasio yang mengukur kemampuan perusahaan untuk memenuhi kewajiban finansial jangka pendeknya.

2. Rasio Leverage, adalah rasio yang mengukur seberapa jauh perusahaan dibelanjai dengan hutang.

3. Rasio Aktivitas, adalah rasio yang mengukur seberapa efektif perusahaan menggunakan sumber dananya.

4. Rasio Profitabilitas, adalah rasio yang mengukur hasil akhir dari sejumlah kebijaksanaan dan keputusan keputusan.

Menurut penjelasan diatas analisis rasio keuangan melibatkan dua data yaitu data dari neraca dan data dari laporan laba rugi dan dengan rasio ini dapat diketahui tingkat likuiditas, tingkat solvabilitas, tingkat aktivitas, dan tingkat profitabilitas, serta tingkat pertumbuhan dan juga penilaian perusahaan. Melalui analisis yang dilakukan maka akan diperoleh gambaran mengenai kinerja perusahaan yang akan memberikan penilaian terhadap perusahaan dan juga dalam pengambilan keputusan serta mempertahankan perusahaan.

Rasio merupakan suatu hubungan antara suatu jumlah tertentu dengan jumlah lain, dengan menggunakan alat analisis berupa rasio ini akan dapat menjelaskan atau memberikan gambaran kepada penganalisis tentang baik atau buruknya keadaan keuangan suatu perusahaan terutama apabila angka rasio tersebut dibandingkan dengan angka rasio pembanding yang digunakan sebagai standar.

\section{a. Rasio likuiditas}

Menurut Fred Weston dalam buku Kasmir (2011: 129), mengatakan bahwa rasio likuiditas adalah Rasio likuiditas (liquidity ratio) merupakan rasio yang menggambarkan kemampuan perusahaan dalam memenuhi kewajiban (utang) jangka pendek.

Adapun menurut Sofyan Syafri Harahap (2013: 301), mendefinisikan rasio likuiditas adalah Rasio likuiditas menggambarkan 
kemampuan perusahaan untuk menyelesaikan kewajiban jangka pendeknya.

Sedangkan menurut Irham Fahmi (2015: 121), mengatakan bahwa rasio likuiditas adalah Kemampuan suatu perusahaan memenuhi kewajiban jangka pendeknya secara tepat waktu.

Berdasarkan beberapa definisi yang telah diungkapkan diatas dapat disimpulkan bahwa rasio likuiditas adalah rasio yang menggambarkan kemampuan perusahaan untuk memenuhi atau membayar kewajiban jangka pendeknya secara tepat waktu.

\section{Jenis - Jenis Rasio Likuiditas}

Jenis-jenis rasio likuiditas yang dapat digunakan perusahaan untuk mengukur kemampuan perusahaan membayar liabilitas jangka pendeknya, yaitu :

1. Rasio Lancar (Current Ratio). Menurut Sofyan Syafri Harahap (2013: 301), merupakan "rasio yang menunjukan sejauh mana aktiva lancar menutupi kewajiban-kewajiban lancar". Semakin besar perbandingan aktiva lancar dengan utang lancar semakin tinggi kemampuan perusahaan menutupi kewajiban jangka pendeknya. Rumus untuk mencari rasio lancar atau current ratio adalah sebagai barikut :

\section{Asset Lancar \\ Current Ratio = ----------- x 100\% Liabilitas Lancar}

2. Rasio Cepat (Quick Ratio). Menurut Kasmir (2011: 136), merupakan rasio yang menunjukan kemampuan perusahaan dalam memenuhi, membayar kewajiban atau utang lancar (utang jangka pendek) dengan aktiva lancar tanpa memperhitungkan nilai sediaan (inventory). Rumus untuk mencari rasio cepat (quick ratio) dapat digunakan sebagai berikut :

Asset Lancar - Persediaan

Quick Ratio= --------------x 100\% Liabilitas Lancar b. Rasio Hutang atau Leverage

Menurut Kasmir (2011: 151) rasio solvabilitas atau leverage ratio merupakan rasio yang digunakan untuk mengatur sejauh mana aktivitas perusahaan dibiayai dengan utang.

Menurut Sofyan Safri Harahap (2013: 303) menyatakan bahwa "rasio solvabilitas menggambarkan kemampuan perusahaan dalam membayar kewajiba jangka panjangnya atau kewajiban - kewajiban lainnya apabila perusahaan dilikuidasi”.

Sedangkan Menurut Irham Fahmi (2015: 62) rasio leverage adalah mengukur seberapa besar perusahaan dibiayai dengan utang.

Menurut penjelasan para ahli di atas rasio solvabilitas merupakan rasio yang dapat menjadi acuan untuk mengatur dan mengukur tingkat liabilitas perusahaan.

Jenis - jenis Rasio Hutang atau Leverage

Menurut Irham Fahmi (2015: 127) jenis - jenis rasio yang ada dalam rasio hutang (leverage) antara lainnya :

1. Debt to Total Assets atau Debt Ratio

Dimana rasio ini disebut juga sebagai rasio yang melihat perbandingan utang perusahaan, yaitu diperoleh dari perbandingan utang perusahaan, yaitu diperoleh dari perbandingan total utang dibagi dengan total asset.

\begin{tabular}{|c|}
\hline Debt Ratio = -------------------- \\
Total Aset
\end{tabular}

2. Debt to equity ratio merupakan sebagai ukuran yang dipakai dalam menganalisis laporan keuangan untuk memperlihatkan besarnya jaminan yang tersedia untuk kreditor.

$$
\text { Debt to Equity Ratio = } \frac{\text { Total Liabilitas }}{\text { Total Ekuitas }}
$$


3. Time interest earned disebut juga dengan rasio kelipatan. Menurut Lyn M. Fraser dan Aileen Orminston (2011: 234) menyatakan bahwa makin tinggi rasio kelipatan pembayaran bunga makin baik, namun jika perusahaan menghasilkan laba yang tinggi, tetapi tidak ada arus kas dari operasi , maka arus kas ini menyesatkan. Membutuhkan uang tunai untuk membayar.

\section{EBIT \\ Beban Bunga}

4. Long Term Debt to Total Capitalization disebut juga dengan utang jangka panjang/total kapitalisasi. long term debt merupakan sumber dana pinjaman yang bersumber dari utang jangka panjang, seperti obligasi dan sejenisnya.

\section{c. Rasio Aktivitas}

Menurut Sofyan Safri Harahap (2013: 308) menyatakan bahwa "rasio aktivitas menggambarkan aktivitas yang dilakukan perusahaan dalam menjalankan kegiatan penjualan, pembelian, dan kegiatan lainnya".

Menurut Irham Fahmi (2015: 132)
rasio aktivitas adalah rasio yang
menggambarkan sejauh mana suatu
perusahaan mempergunakan sumber daya
yang dimilikinya guna menunjang aktivitas
perusahaan, dimana pengguna aktivitas ini
dilakukan seara sangat maksimal dengan
maksud memperoleh hasil yang maksimal.
Berdasarkan pengertian di atas, dapat
disimpulkan bahwa rasio aktivitas digunakan
perusahaan untuk menggambarkan sejauh
mana perusahaan mempergunakan sumber
daya perusahaannya.Rasio aktivitas juga
digunakan untuk menilai kemampuan
perusahaan dalam melaksanakan aktivitas
sehari- hari.

Jenis-Jenis Rasio Aktivitas
1. Inventory Turnover
Persediaan) Menurut Irham (Perputaran

(2015: 132) rasio perputaran persediaan merupakan "rasio yang melihat sejauh mana tingkat perputaran persediaan yang dimiliki oleh perusahaan".

\section{Inventory Harga Pokok Penjualan \\ Turnover $=$ \\ Rata - Rata Persediaan}

2. Working Capital Turn Over (Rasio Perputaran Modal Kerja) menurut Sawir (2010: 16) perputaran modal kerja merupakan rasio mengukur aktivitas bisnis terhadap kelebihan aktiva lancar atas kewajiban lancar serta menunjukkan banyaknya penjualan (dalam rupiah) yang dapat diperoleh perusahaan untuk tiap rupiah modal kerja.

$$
\begin{aligned}
& \text { Working Capital Penjualan Bersih } \\
& \text { Turn Over } \\
& \text { Modal Kerja Bersih }
\end{aligned}
$$

3. Fixed Assets Turnover (Rasio Perputaran Aset Tetap) Menurut Sawir (2003:17) rasio ini merupakan Perbandingan antara penjualan dengan aktiva tetap. Fixed assets turn over mengukur efektivitas penggunaan dana yang tertanam pada harta tetap seperti pabrik dan peralatan, dalam rangka menghasilkan penjualan, atau berapa rupiah penjualan bersih yang dihasilkan oleh setiap rupiah yang diinvestasikan pada aktiva tetap.

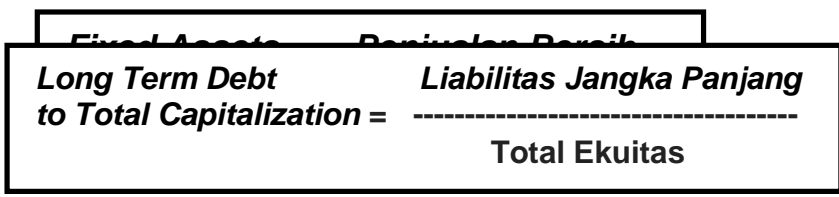

\section{d. Rasio Profitabilitas}

Menurut Kasmir (2011: 196), mengatakan bahwa "Rasio profitabilitas merupakan rasio untuk menilai kemampuan perusahaan dalam mencari keuntungan.Rasio ini juga memberikan 
ukuran tingkat efektivitas manajemen suatu perusahaan."

Adapun menurut Sofyan Safri Harahap (2011: 304), mendefinisikan rasio profitabilitas adalah "Rasio yang menggambarkan kemampuan perusahaan mendapatkan laba melalui semua kemampuan, dan sumber yang ada seperti kegiatan penjualan, kas, modal, jumlah karyawan, jumlah cabang, dan sebagainya."

Sedangkan menurut Irham Fahmi (2015: 135), mengatakan bahwa rasio profitabilitas adalah "Rasio yang mengukur efektivitas secara keseluruhan yang ditunjukan oleh besar kecilnya tingkat keuntungan yang diperoleh dalam hubungannya dengan penjualan maupun investasi."

Berdasarkan beberapa definisi yang telah diungkapkan diatas dapat disimpulkan bahwa rasio profitabilitas adalah rasio yang mengukur atau menilai kemampuan perusahaan dalam memperoleh keuntungan melalui berbagai aktivitas yang dilakukan oleh perusahaan.

\section{Jenis-jenis Rasio Profitabilitas}

Menurut irham fahmi (2015: 135)

\section{Return on Laba Bersih Equity $(\mathrm{ROE})=$ Ekuitas}

menyatakan bahwa "rasio profitabilitas secara umum ada empat macam, yaitu gross profit msrgin, net profit margi, return on investment dan retun on equity".

1. Return on Investment (ROI) menurut Irham Fahmi (2015: 137), Rasio return on investmen (ROI) atau pengembalian investasi, atau ditulis juga dengan return on total asset (ROA) rasio ini melihat

\begin{tabular}{|c|c|}
\hline \multirow{2}{*}{\multicolumn{2}{|c|}{$\begin{array}{l}\text { Penjualanbersih-HPP } \\
\text { Gross profit = } \\
\text {------------------- } \\
\text { Penjualan bersih }\end{array}$}} \\
\hline & \\
\hline $\begin{array}{l}\text { sejauh mana } \\
\text { ditanamkan } \\
\text { pengembalian } \\
\text { dengan yang dih }\end{array}$ & 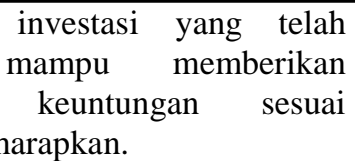 \\
\hline
\end{tabular}

\begin{tabular}{|lc|}
\hline $\begin{array}{l}\text { Return on } \\
\text { Investment }(\mathrm{ROI})=\end{array}$ & $\begin{array}{c}\text { Laba bersih } \\
\text { setelah pajak }\end{array}$ \\
\hline- Total Asset \\
\hline
\end{tabular}

2. Return on Equity (ROE) menurut Irham Fahmi (2015: 137), "rasio return on equity (ROE) disebut juga laba atas ekuitas. Dalam beberapa referensi disebut juga dengan rasio total asset turnover atau perputaran total asset. Rasio ini menilai sejauh mana suatu perusahaan mempergunakan seumber daya yang dimiliki untuk mampu

\section{Laba bersih setelah pajak \\ Net profit margin = Penjualan bersih}

memberikan laba atas ekuitas.

3. Gross profit Menurut Joel G. Siegel dan Jae K. Shim (2011: 216) gross profit margin merupakan "persentase dari sisa penjualan setelah sebuah perusahaan membayar barangnya, juga disebut margin keuntungan kotor (gross profit margin).

4. Net profit margin menurut Joel G. Siegel dan Jae K. Shim (2011: 136) menyatakan bahwa:

a. Margin laba bersih sama dengan laba bersih dibagi dengan penjualan bersih. Ini menunjukan kesetabilan kesatuan untuk menghasilkan perolehan pada tingkat penjualan khusus. Dengan memeriksa margin laba dengan norma industry sebuah perusahaan pada tahun - tahun sebelumnya.

b. Margin laba kotor sama dengan laba kotor dibagi laba bersih. Margin laba yang tinggi lebih disukai karena menunjukan perusahaan mendapat hasil yang baik yang melebihi harga pokok penjualan.

\subsection{Kelebihan Rasio Keuangan}

Menurut Sofyan Syafri Harahap yang dikutip oleh Irham Fahmi (2015: 47) mengemukakan kelebihan rasio keuangan sebagai berikut: 
1. Rasio merupakan angka - angka atau ikhtisar statistik yang lebih mudah dibaca dan ditafsirkan;

2. Merupakan pengganti yang lebih sederhana dari informasi yang disajikan laporan keuangan yang sangat rumit dan rinci;

3. Mengetahui posisi perusahaan di tengah industri lain;

4. Sangat bermanfaat untuk bahan dalam mengisi model model pengambilan keputusa dan model prediksi (Z-score);

5. Menstandarisasi size perusahaan;

6. Lebih mudah memperbandingkan perusahaan dengan perusahaan lain atau melihat perkembangan perusahaan secara periodik atautime series.

7. Lebih mudah melihat tren perusahaan serta melakukan prediksi dimasa yang akan datang."

Menurut Harahap (2010: 298), analisis rasio mempunyai keunggulan dibandingkan teknik analisa lainnya, yaitu :

1. Rasio merupakan angka-angka atau ikhtisar statistik yang lebih mudah dibaca dan ditafsirkan.

2. Merupakan pengganti yang lebih sederhana dari informasi yang disajikan laporan keuangan yang sangat rinci dan rumit.

3. Mengetahui posisi perubahan ditengah industri lain.

4. Sangat bermanfaat untuk bahan dalam mengisi model-model pengambilan keputusan dan model prediksi.

5. Menstandarisir ukuran perusahaan.

6. Lebih mudah memperbandingkan perusahaan dengan perusahaan lain atau melihat perkembangan perusahaan secara periodik atau time series.

7. Lebih mudah melihat trend perusahaan serta melakukan prediksi dimasa yang akan datang.

Rasio keuangan adalah angka yang diperoleh dari perbandingan antara pos - pos yang terkandung dalam laporan keuangan yang mempunyai hubungan signifikan. Rasio keuangan menyederhanakan informasi dari laporan keuangan dan informasi yang terkandung dalam pos - pos laporan keuangan sehingga dapat memberikan penilaian dan keputusan bagi para pemakai laporan keuangan.

\subsection{Keterbatasan Rasio Keuangan}

Keterbatasan dari rasio keuangan berkaitan erat dengan sifat laporan keuangan itu sendiri, menurut Irham Fahmi (2015: 48) mengemukakan keterbatasan rasio keuangan sebagai berikut:

1. Pengunaan rasio keuangan akan memberikan pengukuran yang relative terhadap kondisi suatu perusahaan. Sisi relatif disini yang dimaksudkan bahwa seperti yang dikemukakan Helfert dimana rasio - rasio keuangan bukanlah merupakan kriteria mutlak. Pada kenyataanya analisis rasio keuangan hanyalah suatu titik awal dalam analisis laporan keuangan perusahaan.

2. Analisis rasio keuangan hanya dapat dijadikan sebagai peringatan awal dan bukan kesimpulan akhir. Ini sebagaimana yang diaktan oleh Friedlob dan Plewa menyebutkan analisis laporan rasio tidak memberikan banyak jawaban kecuali memberikan rambu rambu tentang apa yang seharusnya diharapkan.

3. Setiap data yang diperoleh yang dipergunakan dalam menganalisa adalah bersumber dari laporan keungan perusahaan. Maka sangat memungkinkan data yang diperoleh tersebut merupakan adalah data yang angkanya tidak memiliki tingkat keakuratan yang tinggi, dengan alasan mungkin saja data - data tersebut diubah dan disesuaikan berdasrkan kebutuhan.

4. Pengukuran rasio keuangan banyak yang bersifat artificial. Artifical disini artinya perhitungan rasio keuangan tersebut dilakukan oleh manusia, dan setiap pihak memiliki pandangan yang berbeda-beda dalam menempatkan ukuran terutam justifikasi dipergunakannya rasio - rasio tersebut." Menurut Harahap (2010: 298), keterbatasan analisis rasio itu adalah:

1. Kesulitan dalam memilih rasio yang tepat yang dapat digunakan untuk kepentingan pemakai.

2. Keterbatasan yang dimiliki akuntansi atau laporan keuangan juga menjadi keterbatasan teknik seperti ini.

3. Jika data untuk menghitung rasio tidak tersedia, akan menimbulkan kesulitan menghitung rasio.

4. Sulit jika data yang tersedia tidak singkron. 
Berdasarkan keterangan di atas apabila dua perusahaan yang dibandingkan bisa saja teknik dan standar akuntansi yang dipakai tidak sama. Oleh karenanya jika dilakukan perbandingan bisa menimbulkan kesalahan.

\subsection{Efisiensi Modal Kerja}

Modal kerja selalu dalam keadaan operasi atau berputar dalam perusahaan selama perusahaan yang bersangkutan dalam keadaan usaha. Periode perputaran modal kerja dimulai dari saat dimana kas diinvestasikan dalam komponen - komponen modal kerja sampai saat dimana kembali lagi menjadi kas.

Pengukuran efisiensi penggunaan modal kerja, peneliti dapat menggunakan perputaran modal kerja (working capital turnover). Working Capital Turnover (WCT) yaitu rasio yang memperlihatkan adanya keefektifan dan keefisienan modal kerja dalam pencapaian penjualan.

Ditegaskan menurut Kasmir (2011: 182), yang menyatakan bahwa "Perputaran modal kerja atau working capital turn over merupakan salah satu rasio untuk mengukur atau menilai keefektifan dan kefisienan modal kerja perusahaan selama periode tertentu".

Sedangkan menurut Jumingan (2014: 132) "Untuk menguji efisiensi penggunaan modal kerja dapat menggunakan perputaran modal kerja (working capital turnover), yakni rasio antara penjualan neto dengan modal kerja bersih". Artinya seberapa banyak modal kerja berputar selama satu periode atau dalam satu periode.

Dari penjelasan di atas terdapat hubungan antara penjualan neto dengan modal kerja neto, yang dapat disimpulkan perputaran modal kerja ini menunjukan jumlah rupiah penjualan neto yang diperoleh bagi setiap rupiah modal kerja neto.

\subsection{Debt To Equity}

Debt to equity merupakan rasio keuangan yang menunjukan proporsi relative dari ekuitas dan liabilitas yang digunakan untuk membiayai asset perusahaan. Debt to equity mencerminkan kemampuan perusahaan dalam memenuhi seluruh liabilitasnya yang ditunjukan oleh beberapa bagian modal sendiri yang digunakan untuk mem bayar liabilitas. Debt to equity juga memberikan jaminan seberapa besar liabilitas perusahaan dijamin oleh modal sendiri yang digunakan sebagai pendanaan perusahaan.

Semakin tinggi nilai debt to equity menggambarkan semakin buruk kondisi perusahaantersebut karena menandakan struktur pendanaan perusahaan lebih banyak berhutang disbandingkan modal yang dimiliki perusahaan sendii. Sebaliknya semakin rendah rasio ini semakin baik kondisi perusahaan.

Menurut Irham Fahmi (2015: 127), Debt to equity ratio merupakan sebagai ukuran yang dipakai dalam menganalisis laporan keuangan untuk memperlihatkan besarnya jaminan yang tersedia untuk kreditor.

Rasio ini memperlihatkan sejauhmana modal kerja dibiayai oleh liabilitas dibanding modal sendiri, apabila modal kerja lebih besar dibiayai oleh liabiltas dibanding modal sendiri, perusahaan akan mengalami kesulitan pada saat perusahaan dalam masa kemerosotan, karena modal kerja sendiri tidak dapat membayar libilitas perusahaan.

\subsection{Retun On Equity}

Return on equity merupakan rasio yang umum digunakan untuk mengukur hasil pengembalian investasi atas pemilik modal atau ekuitas menurut Kasmir (2011:204) "bahwa hasil pengembalian ekuitas atau return on equity atau rentabilitas modal sendiri merupakan rasio untuk mengukur laba bersih sesudah pajak dengan modal sendiri".

Sedangkan menurut Irham Fahmi (2015: 137),"return on equity (ROE) disebut juga laba atas ekuitas". Rasio ini menilai sejauh mana suatu perusahaan mempergunakan seumber daya yang dimiliki untuk mampu memberikan laba atas ekuitas.

Berdasarkan pendapat di atas tersebut dapat disimpulkanbbahwa return on equity merupakan perbandingan antara laba bersih setelah pajak dengan modal sendiri, secara umumbsemakin tinggi return on equity yang diperoleh maka semakin baik kedudukan perusahaan tersebut.

Return on equity dapat dijadikan salah satu indikator yang digunakan untuk mengukur keberhasilan kinerja suatu perusahaan yang menggambarkan tingkat 
pengembalian laba atas seluruh modal yang ada. Return on equity diukur dalam dalam satuan persen, semakin tinggi persentase yang diperoleh oleh perusahaan menunjukan semakin tinggi pengelolaan modal perusahaan dalam mendapatkan laba atas modal tersebut.

Suatu perusahaan dianggap baik jika peroleh return on equity perusahaan lebih tinggi dari rata - rata industry, ini dikarenakan tingkat pengembalian yanag akan diperoleh pemegang saham menjadi lebih tinggi, sebaliknya perusahaan dianggap kurang baik jika perolehan return on equity perusahaan lebih rendah dari rata - rata industry.

\section{Metode Penelitian yang digunakan}

Metode penelitian merupakan cara ilmiah untuk mendapatkan data dengan tujuan dan kegunaan tertentu. Cara ilmiah berarti kegiatan penelitian ini berdasarkan ciri - ciri keilmuan yang terdiri dari rasional, empiris, dan sistematis. Rasional berarti kegiatan penelitian itu dilakukan dengan cara - cara yang masuk akal, sehingga terjangkau oleh penalaran manusia. Empiris berarti cara - cara yang dilakukan itu dapat diamati oleh indera manusia, sehingga orang lain dapat mengamati dan mengetahui cara cara yang digunakan. Sistematis berarti proses yang digunakan dalam penelitian itu menggunakan langkah - langkah tertentu yang bersifat logis.

Selanjutnya penelitian ini menggunakan metode penelitian kuantitatif dengan pendekatan deskriptif dan asosiatif.

Menurut Sugiyono (2012: 53) menyatakan bahwa rumusan deskriptif adalah suatu rumusan masalah yang berkenaan dengan pertanyaan terhadap keberadaan variabel mandiri, baik hanya pada satu variabel atau lebih, variabel mandiri adalah variabel yang berdiri sendiri, bukan variabel independen, karena kalau variabel independen selalu dipasangkan dengan variabel dependen.

Sugiyono (2012: 55) menyatakan bahwa "rumusan asosiatif adalah suatu pertanyaan penelitian bersifat menanyakan hubungan antara dua variabel atau lebih".

\subsection{Obyek Penelitian Perusahaan}

Obyek penelitian yang digunakan dalam penelitian ini adalah perusahaan manufaktur sektor food and bevereges atau makanan dan minuman periode 2009 - 2013. Berikut ini adalah nama - nama perusahaan food and bevereges beserta kode perusahaan yang terpilih menjadi obyek penelitian ini.

Tabel 4.1

Nama perusahaan yang menjadi obyekpenelitian

\begin{tabular}{|l|l|l|}
\hline No & Nama Perusahaan & Kode \\
\hline 1. & $\begin{array}{l}\text { PT. AkshaWira } \\
\text { Internasional Tbk }\end{array}$ & ADES \\
\hline 2. & $\begin{array}{l}\text { PT. Tiga Pilar Sejahtera } \\
\text { Food Tbk }\end{array}$ & AISA \\
\hline 3. & $\begin{array}{l}\text { PT. Wilmar Cahaya } \\
\text { Indonesia Tbk }\end{array}$ & CEKA \\
\hline 4. & PT. Delta Jakarta Tbk & DLTA \\
\hline 5. & $\begin{array}{l}\text { PT. Indofood Sukses } \\
\text { Makmur Tbk }\end{array}$ & INDF \\
\hline 6. & PT. Mayora Indah Tbk & MYOR \\
\hline 7. & PT. Sekar Laut Tbk & SKLT \\
\hline 8. & PT. Siantar Top Tbk & STTP \\
\hline 9. & $\begin{array}{l}\text { PT. Ultrajaya Milk Industry } \\
\& \text { Trading Company Tbk }\end{array}$ & ULTJ \\
\hline
\end{tabular}

\subsection{Pengukuran Tingkat Efisiensi Modal} Kerja dengan Working Capital Turn Over (WCT).

Modal kerja merupakan sejumlah dana yang dimiliki oleh perusahan yang dipergunakan untuk membiayai seluruh kegiatan perusahaan. Dalam karya ilmiah ini modal kerja perusahaan diambil dari konsep kuantitatif yaitu total aktiva lancar yang dimiliki perusahaan.

Working capital turn over (WCT) merupakan salah satu rasio aktivitas yang mengukur tingkat perputaran modal kerja dalan satu periode, adapun rumus Working capital turn over di halam berikutnya yaitu:

Tabel 4.2

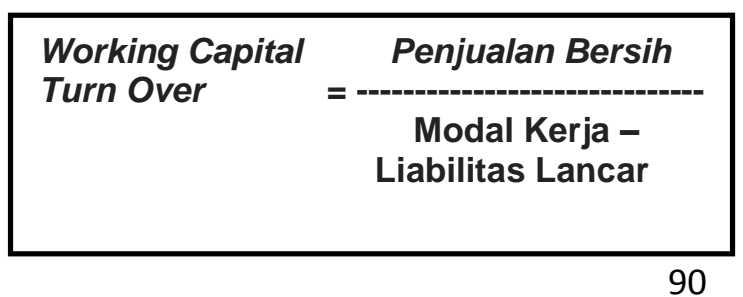


Total Modal Kerja Perusahaan food and bevereges Periode 2009 - 2013 (dalam jutaan rupiah)

\begin{tabular}{|l|r|r|r|r|r|}
\hline \multicolumn{7}{|c|}{ Modal Kerja } \\
\hline Ko & $\mathbf{2 0 0 9}$ & $\mathbf{2 0 1 0}$ & $\mathbf{2 0 1 1}$ & $\mathbf{2 0 1 2}$ & $\mathbf{2 0 1 3}$ \\
\hline AD & 43,93 & 44,65 & 53,44 & 92,86 & 109,4 \\
ES & 8 & 6 & 1 & 5 & 72 \\
\hline AIS & 63,98 & 147,7 & 814,7 & 327,9 & 1,129, \\
A & 6 & 15 & 45 & 43 & 440 \\
\hline CE & 297,8 & 258,8 & 252,1 & 14,79 & 287,7 \\
KA & 80 & 87 & 31 & 3 & 28 \\
\hline DL & 482,6 & 482,5 & 481,5 & 511,4 & 523,8 \\
TA & 65 & 57 & 16 & 13 & 30 \\
\hline IN & 1,795 & 10,21 & 11,67 & 13,12 & 12,99 \\
DF &, 851 & 8,876 & 0,430 & 2,428 & 3,188 \\
\hline MY & 986,1 & 1,644, & 2,249, & 3,389, & 3,413, \\
OR & 94 & 520 & 507 & 166 & 801 \\
\hline SK & 41,40 & 45,41 & 43,20 & 36,84 & 35,55 \\
LT & 4 & 8 & 1 & 2 & 4 \\
\hline ST & 75,73 & 120,8 & 10,55 & 569,8 & 70,71 \\
TP & 4 & 70 & 2 & 40 & 7 \\
\hline UL & 380,7 & 429,0 & 477,8 & 316,4 & 577,1 \\
TJ & 44 & 48 & 84 & 86 & 49 \\
\hline
\end{tabular}

Sumber : Data diolah dengan Ms. Excel

Tabel 4.3

Total Pendapatan Perusahaan Food and Bevereges Periode 2009 - 2013 (dalam jutaan rupiah)

\begin{tabular}{|c|r|r|r|r|r|}
\hline \multicolumn{7}{|c|}{ Pendapatan } \\
\hline $\begin{array}{c}\text { Ko } \\
\text { de }\end{array}$ & $\mathbf{2 0 0 9}$ & $\mathbf{2 0 1 0}$ & $\mathbf{2 0 1 1}$ & $\mathbf{2 0 1 2}$ & $\mathbf{2 0 1 3}$ \\
\hline AD & 134,4 & 218,7 & 299,4 & 476,6 & 378, \\
ES & 38 & 48 & 09 & 38 & 997 \\
\hline AI & 533,1 & 705,2 & 1,752 & 2,747 & 2,94 \\
SA & 94 & 20 &, 802 &, 623 & 4,80 \\
\hline CE & 1,194 & 718,2 & 1,238 & 1,123 & 1,72 \\
KA &, 544 & 05 &, 169 &, 520 & 2,99 \\
\hline DL & 740,6 & 547,8 & 564,0 & 1,719 & 609 \\
TA & 81 & 16 & 51 &, 815 & 526 \\
\hline IN & 37,14 & 38,40 & 45,33 & 50,05 & 5,73 \\
DF & 0,830 & 3,360 & 2,256 & 9,427 & 1,99 \\
\hline M & 4,777 & 7,224 & 9,453 & 10,51 & 8,58 \\
YO &, 175 &, 165 &, 866 & 0,626 & 8,23 \\
R & & & & 4 \\
\hline SK & 276,3 & 314,1 & 344,4 & 401,7 & 405, \\
LT & 12 & 46 & 36 & 24 & 592 \\
\hline ST & 627,1 & 762,6 & 1,027 & 1,283 & 1,23 \\
TP & 15 & 13 &, 684 &, 736 & 2,49 \\
\hline UL & 1,362 & 1,613 & 1,880 & 2,102 & 2,06 \\
TJ &, 607 &, 928 &, 441 &, 384 & 4,37 \\
\hline
\end{tabular}

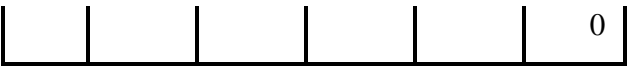

Sumber : Data diolah dengan Ms.

Excel

Tabel 4.4

Tingkat Working Capital Turn Over Perusahaan Food and Bavereges Periode 2009 - 2013

\begin{tabular}{|l|r|r|r|r|r|}
\hline \multicolumn{7}{|c|}{ WORKING CAPITAL TURN OVER } \\
\hline $\begin{array}{l}\text { Nama } \\
\text { Perusaha }\end{array}$ & $\mathbf{2 0 0 9}$ & $\mathbf{2 0 1 0}$ & $\mathbf{2 0 1 1}$ & $\mathbf{2 0 1 2}$ & $\mathbf{2 0 1 3}$ \\
\hline ADES & 3.06 & 4.90 & 5.60 & 5.13 & 3.46 \\
\hline AISA & 8.33 & 4.77 & 2.15 & 8.38 & 2.61 \\
\hline CEKA & 4.01 & 2.78 & 4.91 & 75.94 & 5.99 \\
\hline DLTA & 1.53 & 1.13 & 1.17 & 3.36 & 1.16 \\
\hline INDF & 20.68 & 3.75 & 3.89 & 3.81 & 4.44 \\
\hline MYOR & 4.84 & 4.40 & 4.20 & 3.10 & 2.51 \\
\hline SKLT & 6.67 & 6.92 & 7.97 & 10.90 & 11.41 \\
\hline STTP & 8.28 & 6.31 & 97.39 & 2.25 & 17.43 \\
\hline ULTJ & 3.58 & 3.76 & 3.93 & 6.64 & 3.58 \\
\hline Rata-rata & 6.78 & 4.30 & 14.58 & 13.28 & 5.84 \\
\hline
\end{tabular}

Sumber: data diolah dengan Ms. Excel

Berdasarkan data di atas, rata - rata tingkat efisiensi modal kerja (Working Capital Turn Over) pada tahun 2009 sebesar 6.78 kali modal kerja berputar dalam satu periode, lalu tingkat tingkat efisiensi modal kerja (Working Capital Turn Over) pada tahun 2010 perputaran modal kerja menurun menjadi 4.30 kali dalam satu periode, dan pada tahun 2011 tingkat efisiensi modal kerja (Working Capital Turn Over) perputan modal kerja kembali naik menjadi 14.58 kali dalam satu periode, serta pada tahun 2012 naik kembali menjadi 13,28 kali dalam satu periode. Dan pada tahun 2013 tingkat perputaran modal kerja menurun kembali menjadi 5.84. efisiensi modal kerja (Working Capital Turn Over) yang terjadi dari tahun 2009 - 2013 bersifat fluktuatif, akan tetapi kenaikan dan penurunannya tidak terlalu drastis.

Pada tahun 2009, seluruh tingkat efisiensi modal kerja (Working Capital Turn Over) yang tertinggi dimiliki oleh PT. Indofood Sukses Makmur Tbk yaitu sebesar 20,68 kali modal kerja berputar dalam satu periode, pada tahun 2010 efisiensi modal kerja (Working Capital Turn Over) tertinggi dimiliki oleh PT. Sekar Laut Tbk sebesar 6,92, pada tahun 2011 efisiensi modal kerja (Working Capital Turn Over) tertinggi dimiliki oleh PT. Siantar Top Tbk sebesar 97,39, dan pada tahun 2012 efisiensi modal kerja (Working Capital Turn Over) tertinggi dimiliki oleh PT. Wilmar Cahaya Indonesia Tbk sebesar 75,94, serta pada tahun 2013 sebesar 17,43. 
Tingkat efisiensi modal kerja (Working Capital Turn Over) yang dimiliki oleh PT. Siantar Top Tbk menjelaskan bahwa perusahaan tersebut memiliki efisiensi modal kerja yang tinggi, karena mampu memutarkan modal kerjanya seoptimal mungkin.

Untuk tingkat efisiensi modal kerja (Working Capital Turn Over) terendah pada tahun 2009 - 2013 dimliki oleh PT. Delta Jakarta yaitu pada tahun 2009 sebesar 1,53, tahun 2010 sebesar 1,13, tahun 2011 sebesar1,17,tahun 2012 sebesar 3,36 dan tahun 2013 sebesar 1,16.

Tingkat efisiensi modal kerja (Working Capital Turn Over) yang rendah dapat di artikan bahwa perusahaan tersebut kurang bisa mengunakan modal kerja secara efisien hingga berdampak pada rendahnya tingkat perputaran modal kerja.

\subsection{Pengukuran Tingkat Debt to Equity}

Debt to equty merupakan salah satu rasio solvabilitas yang mengukur total liabilitas dengan total ekuitas, yang menjelaskan apakah total liabilitas perusahaan bisa ditangguhkan oleh total ekuitas pada saat perusahaan dilikuidasi.

Apabila nilai rasio ini lebih dari angka satu maka dapat disimpulkan bahwa total ekuitas perusahaan tidak mampu menangguhkan total liabilitas perusahaan pada saat dilikuidasi.

Adapun debt to equity dapat dihitung dengan rumus:

Tabel 4.5

Total liabilitas perusahaan food and bevereges periode 2009 - 2013 (dalam jutaan rupiah)

\begin{tabular}{|l|r|r|r|r|r|}
\hline $\begin{array}{c}\text { Kod } \\
\text { e }\end{array}$ & $\mathbf{2 0 0 9}$ & $\mathbf{2 0 1 0}$ & $\mathbf{2 0 1 1}$ & $\mathbf{2 0 1 2}$ & $\mathbf{2 0 1 3}$ \\
\hline & & & & & \\
\hline ADE & 110,0 & 224,6 & 190,3 & 179,9 & 168,5 \\
S & 68 & 15 & 02 & 72 & 15 \\
\hline AIS & 918,1 & 1,346 & 1,757 & 1,834 & 2,483 \\
A & 70 &, 881 &, 492 &, 123 &, 269 \\
\hline
\end{tabular}

\begin{tabular}{|l|r|r|r|r|r|}
\hline \multicolumn{5}{|c|}{ Total Liabilitas } \\
Debt to Equity Ratio = --------------- \\
Total Ekuitas
\end{tabular}

\begin{tabular}{|l|r|r|r|r|r|} 
A & 08 & 25 & 21 & 95 & 76 \\
\hline IND & 24,88 & 22,42 & 21,97 & 25,18 & 39,71 \\
F & 6,781 & 3,117 & 5,708 & 1,533 & 9,660 \\
\hline MY & 1,623 & 2,359 & 4,175 & 5,234 & 5,265 \\
OR & 443 &, 028 &, 176 &, 656 &, 785 \\
\hline SKL & 82,71 & 81,07 & 93,11 & 120,2 & 147,7 \\
T & 5 & 0 & 8 & 64 & 02 \\
\hline STT & 144,2 & 201,9 & 444,7 & 670,1 & 717,5 \\
P & 11 & 34 & 01 & 49 & 80 \\
\hline ULT & 603,9 & 538,1 & 705,4 & 776,7 & 761,6 \\
J & 96 & 64 & 72 & 35 & 69 \\
\hline Rata & $\mathbf{3 , 2 0 3}$ & $\mathbf{3 , 0 6 6}$ & $\mathbf{3 , 3 1 8}$ & $\mathbf{3 , 8 4 5}$ & $\mathbf{5 , 5 4 6}$ \\
-rata & $\mathbf{5 2 2}$ & $\mathbf{, 5 3 2}$ & $\mathbf{9 2 8}$ & $\mathbf{, 3 2 6}$ & $\mathbf{3 6 5}$ \\
\hline
\end{tabular}

Sumber : Data diolah dengan Ms.

Excel

Tabel 4.6

Total ekuitas perusahaan food and bevereges periode 2009 - 2013 (dalam jutaan ruipiah)

\begin{tabular}{|l|r|r|r|r|r|}
\hline $\begin{array}{l}\text { Kod } \\
\text { e }\end{array}$ & $\mathbf{2 0 0 9}$ & $\mathbf{2 0 1 0}$ & $\mathbf{2 0 1 1}$ & $\mathbf{2 0 1 2}$ & $\mathbf{2 0 1 3}$ \\
\hline ADE & 68,21 & 99,87 & 125,7 & 209,1 & 259,1 \\
S & 9 & 8 & 46 & 22 & 47 \\
\hline AIS & 428,4 & 590,0 & 1,832 & 2,033 & 2,260 \\
A & 42 & 69 &, 817 &, 453 &, 661 \\
\hline CEK & 301,5 & 308,7 & 405,0 & 463,4 & 503,6 \\
A & 03 & 53 & 59 & 03 & 28 \\
\hline DLT & 590,2 & 577,6 & 572,9 & 598,2 & 606,2 \\
A & 26 & 68 & 35 & 12 & 62 \\
\hline IND & 10,11 & 16,78 & 31,61 & 34,14 & 38,37 \\
F & 5,495 & 4,671 & 0,225 & 2,674 & 3,129 \\
\hline MY & 1,581 & 1,991 & 2,424 & 3,067 & 3,664 \\
OR &, 755 &, 295 &, 669 &, 850 &, 500 \\
\hline SKL & 113,4 & 118,3 & 122,9 & 129,4 & 138,7 \\
T & 68 & 01 & 00 & 83 & 03 \\
\hline STT & 404,5 & 447,1 & 490,0 & 579,6 & 666,5 \\
P & 09 & 40 & 65 & 91 & 50 \\
\hline ULT & 1,135 & 1,191 & 1,297 & 1,402 & 1,548 \\
J &, 324 &, 583 &, 953 &, 447 &, 334 \\
\hline Rata & $\mathbf{1 , 6 3 7}$ & $\mathbf{2 , 4 5 6}$ & $\mathbf{4 , 3 2 0}$ & $\mathbf{4 , 7 3 6}$ & $\mathbf{5 , 3 3 5}$ \\
-rata & $\mathbf{6 6 0}$ & $\mathbf{5 9 5}$ & $\mathbf{2 6 3}$ & $\mathbf{2 5 9}$ & $\mathbf{6 5 7}$ \\
\hline
\end{tabular}

Excel

Sumber : Data diolah dengan Ms.

Tabel 4.7

Tingkat debt to equity perusahaan food and bevereges periode 2009 - 2013

\begin{tabular}{|c|c|c|c|c|c|}
\hline Kode & $\begin{array}{c}200 \\
9 \\
\end{array}$ & $\begin{array}{c}201 \\
0 \\
\end{array}$ & $\begin{array}{c}201 \\
1 \\
\end{array}$ & $\begin{array}{c}201 \\
2 \\
\end{array}$ & $\begin{array}{c}201 \\
3 \\
\end{array}$ \\
\hline ADES & 1.16 & 2.25 & 1.51 & 0.86 & 0.65 \\
\hline AISA & 2.14 & 2.28 & 0.96 & 0.9 & 1.1 \\
\hline CEKA & 0.89 & 1.75 & 1.03 & 1.22 & 0.86 \\
\hline DLTA & 0.27 & 0.2 & 0.22 & 0.25 & 0.25 \\
\hline INDF & 2.45 & 1.34 & 0.7 & 0.74 & 1.04 \\
\hline MYOR & 1.03 & 1.18 & 1.72 & 1.71 & 1.44 \\
\hline
\end{tabular}




\begin{tabular}{|l|l|l|l|l|l|}
\hline SKLT & 0.73 & 0.69 & 0.74 & 0.93 & 1.06 \\
\hline STTP & 0.36 & 0.45 & 0.91 & 1.16 & 1.08 \\
\hline ULTJ & 0.53 & 0.45 & 0.54 & 0.55 & 0.49 \\
\hline $\begin{array}{l}\text { Rata- } \\
\text { rata }\end{array}$ & $\mathbf{1 . 0 6}$ & $\mathbf{1 . 1 8}$ & $\mathbf{0 . 9 3}$ & $\mathbf{0 . 9 2}$ & $\mathbf{0 . 8 9}$ \\
\hline
\end{tabular}

Sumber : Data diolah dengan Ms. Excel

Berdasarkan data di atas, rata-rata tingkat debt to equity pada tahun 2009 sebesar 1,06, lalu meningkat pada tahun berikutnya yaitu tahun 2010 sebesar 1,18 , kemudian pada tahun 2011 rata-rata tingkat debt to equity menurun menjadi 0,93 , dan pada tahun 2012 turun kembali menjadi 0,92 , serta pada tahun 2013 rata-rata tingkat debt to equity kembali turun yaitu sebesar 0,89 . Tingkat debt to equity yang terjadi dari tahun 2009-2013 bersifat fluktuatif, akan tetapi kenaikan dan penurunannya tidak terlalu drastis.

Tingkat debt to equity pada tahun 2009 yang tertinggi dimiliki oleh PT. Indofood Sukses Makmur Tbk, yaitu sebesar 2,45, lalu pada tahun 2010 tingkat debt to equity yang tinggi dimiliki oleh PT. AkshaWira Internasional Tbk yaitu sebesar 2,25, kemudian pada tahun 2011 dimiliki oleh PT. Mayora Indah Tbk yaitu sebesar 1,72, dan pada tahun 2012 tingat debt to equity yang paling tinggi dimiliki oleh PT. Mayora Indah Tbk yaitu sebesar 1,71, serta pada tahun 2013 debt to equity paling tinggi dimiliki oleh PT. Mayora Indah Tbk yaitu sebesar 1,44 .

\subsection{Pengukuran Tingkat Return on Equity}

Return on equity merupakan salah satu rasio profitabilitas yang membadingkan laba bersih dengan total ekuitas, menjelaskan bahwa bagaimana perusahaan mampu mengembalikan modal ekuitas yang dipergunakan untuk membiayai kegiatan perusahaan.

Semakin besar rasio ini maka semakin besar. Adapun rumus untuk menghitung return on equity yaitu:

Tabel 4.8

Tingkat laba bersih perusahaan food and bevereges periode 2009 - 2013 (dalam jutaan rupiah)

\begin{tabular}{|l|r|r|r|r|r|}
\hline $\begin{array}{l}\text { Kod } \\
\text { e }\end{array}$ & $\mathbf{2 0 0 9}$ & $\mathbf{2 0 1 0}$ & $\mathbf{2 0 1 1}$ & $\mathbf{2 0 1 2}$ & $\mathbf{2 0 1 3}$ \\
\hline ADE & 16,3 & 31,6 & 25,8 & 83,3 & 50,0 \\
S & 21 & 59 & 68 & 76 & 25 \\
\hline AIS & 37,8 & 80,0 & 149, & 253, & 250, \\
A & 23 & 66 & 951 & 664 & 618 \\
\hline CEK & 50,6 & 29,5 & 96,3 & 58,3 & 40,2 \\
A & 57 & 62 & 06 & 44 & 25 \\
\hline DLT & 131, & 146, & 151, & 213, & 192, \\
A & 758 & 056 & 715 & 421 & 202 \\
\hline & 2,85 & 3,93 & 4,89 & 4,77 & 3,41 \\
IND & 6,78 & 4,80 & 1,67 & 9,44 & 6,63 \\
F & 1 & 8 & 3 & 6 & 5 \\
\hline MY & 382, & 499, & 483, & 744, & 773, \\
OR & 503 & 655 & 486 & 428 & 935 \\
\hline SKL & 12,8 & 4,83 & 5,99 & & 9,22 \\
T & 03 & 4 & 7 & 7963 & 1 \\
\hline STT & 41,0 & 41,7 & 42,6 & 74,6 & 86,8 \\
P & 72 & 34 & 75 & 26 & 59 \\
\hline ULT & 303, & 61,1 & 107, & 101, & 174, \\
J & 712 & 53 & 123 & 323 & 771 \\
\hline Rata & 425, & 536, & 661, & 701, & 554, \\
-rata & 937 & 614 & 644 & 843 & 943 \\
\hline & Sur &
\end{tabular}

Sumber : Data diolah dengan Ms. Excel

Tabel 4.9

Tingkat ekuitas perusahaan food and bevereges periode 2009 - 2013 (dalam jutaan rupiah)

$$
\begin{aligned}
& \text { Return on Laba Bersih } \\
& \text { Equity }(\mathrm{ROE})=\text { - }
\end{aligned}
$$

\begin{tabular}{|l|r|r|r|r|r|}
\hline $\begin{array}{c}\text { Kod } \\
\text { e }\end{array}$ & $\mathbf{2 0 0 9}$ & $\mathbf{2 0 1 0}$ & $\mathbf{2 0 1 1}$ & $\mathbf{2 0 1 2}$ & $\mathbf{2 0 1 3}$ \\
\hline AD & 68,2 & 99,8 & 125, & 209, & 259, \\
ES & 19 & 78 & 746 & 122 & 147 \\
\hline & & & 1,83 & 2,03 & 2,26 \\
AIS & 428, & 590, & 2,81 & 3,45 & 0,66 \\
A & 442 & 069 & 7 & 3 & 1 \\
\hline CE & 301, & 308, & 405, & 463, & 503, \\
KA & 503 & 753 & 059 & 403 & 628 \\
\hline DLT & 590, & 577, & 572, & 598, & 606, \\
A & 226 & 668 & 935 & 212 & 262 \\
\hline & 10,1 & 16,7 & 31,6 & 34,1 & 38,3 \\
IND & 55,4 & 84,6 & 10,2 & 42,6 & 73,1 \\
F & 95 & 71 & 25 & 74 & 29 \\
\hline & 1,58 & 1,99 & 2,42 & 3,06 & 3,66 \\
MY & 1,75 & 1,29 & 4,66 & 7,85 & 4,50 \\
OR & 5 & 5 & 9 & 0 & 0 \\
\hline SKL & 113, & 118, & 122, & 129, & 138, \\
T & 468 & 301 & 900 & 483 & 703 \\
\hline
\end{tabular}




\begin{tabular}{|l|r|r|r|r|r|}
\hline STT & 404, & 447, & 490, & 579, & 666, \\
P & 509 & 140 & 065 & 691 & 550 \\
\hline & 1,13 & 1,19 & 1,29 & 1,40 & 1,54 \\
ULT & 5,32 & 1,58 & 7,95 & 2,44 & 8,33 \\
J & 4 & 3 & 3 & 7 & 4 \\
\hline Rat & $\mathbf{1 , 6 3}$ & $\mathbf{2 , 4 5}$ & $\mathbf{4 , 3 2}$ & $\mathbf{4 , 7 3}$ & $\mathbf{5 , 3 3}$ \\
a- & $\mathbf{7 , 6 6}$ & $\mathbf{6 , 5 9}$ & $\mathbf{0 , 2 6}$ & $\mathbf{6 , 2 5}$ & $\mathbf{5 , 6 5}$ \\
rata & $\mathbf{0}$ & $\mathbf{5}$ & $\mathbf{3}$ & $\mathbf{9}$ & $\mathbf{7}$ \\
\hline
\end{tabular}

Sumber : Data diolah dengan Ms.

Excel

Tabel 4.10

Tingkat return on equity perusahaan food and bevereges periode 2009 - 2013

\begin{tabular}{|l|r|r|r|r|r|}
\hline & $\mathbf{2 0 0}$ & $\mathbf{2 0 1}$ & $\mathbf{2 0 1}$ & $\mathbf{2 0 1}$ & $\mathbf{2 0 1}$ \\
Kode & \multicolumn{1}{|c|}{$\mathbf{9}$} & \multicolumn{1}{c|}{$\mathbf{1}$} & \multicolumn{1}{c|}{$\mathbf{2}$} & \multicolumn{1}{c|}{$\mathbf{3}$} \\
\hline & 23.9 & 31.7 & 20.5 & 39.8 & 19.3 \\
ADES & $5 \%$ & $\%$ & $7 \%$ & $7 \%$ & $\%$ \\
\hline & 8.83 & 13.5 & 8.18 & 12.4 & 11.0 \\
AISA & $\%$ & $7 \%$ & $\%$ & $7 \%$ & $9 \%$ \\
\hline CEK & 16.8 & 9.57 & 23.7 & 12.5 & 7.99 \\
A & $\%$ & $\%$ & $8 \%$ & $9 \%$ & $\%$ \\
\hline & 22.2 & 25.2 & 26.4 & 35.6 & 31.7 \\
DLTA & $3 \%$ & $8 \%$ & $8 \%$ & $8 \%$ & $\%$ \\
\hline & 28.1 & 23.4 & 15.4 & & 8.9 \\
INDF & $3 \%$ & $4 \%$ & $7 \%$ & $14 \%$ & $\%$ \\
\hline MYO & 24.1 & 25.0 & 19.9 & 24.2 & 21.1 \\
R & $8 \%$ & $9 \%$ & $4 \%$ & $7 \%$ & $2 \%$ \\
\hline & 11.2 & 4.09 & 4.86 & 6.15 & 6.65 \\
SKLT & $8 \%$ & $\%$ & $\%$ & $\%$ & $\%$ \\
\hline & 10.1 & 9.33 & 8.71 & 12.8 & 13.0 \\
STTP & $5 \%$ & $\%$ & $\%$ & $7 \%$ & $3 \%$ \\
\hline & 23.6 & 8.25 & 15.6 & 11.1 & 21.4 \\
ULTJ & $7 \%$ & $\%$ & $3 \%$ & $8 \%$ & $7 \%$ \\
\hline Rata- & $\mathbf{1 8 . 8}$ & $\mathbf{1 6 . 7}$ & $\mathbf{1 5 . 9}$ & $\mathbf{1 8 . 7}$ & $\mathbf{1 5 . 6}$ \\
rata & $\%$ & $\%$ & $\mathbf{6 \%}$ & $\mathbf{9 \%}$ & $\mathbf{9 \%}$ \\
\hline
\end{tabular}

Sumber: data diolah

dengan Ms. World

Berdasarkan data di atas, rata-rata tingkat profitabilitas (return on equity) pada tahun 2009 sebesar $18,8 \%$, lalu menurun pada tahun berikutnya yaitu tahun 2010 sebesar 16,7\%, kemudian pada tahun 2011 rata-rata tingkat profitabilitas (return on equity) menurun kembali menjadi $15,96 \%$, dan pada tahun 2012 naik menjadi 18,79\%, serta pada tahun 2013 rata-rata tingkat profitabilitas (return on equity) kembali turun yaitu sebesar 15,69\%. Tingkat profitabilitas (return on equity) yang terjadi dari tahun 2009 - 2013 bersifat fluktuatif, akan tetapi kenaikan dan penurunannya tidak terlalu drastis.
Tingkat profitabilitas (return on equity) pada tahun 2009 yang tertinggi dimiliki oleh PT. Indofood Sukses Makmur Tbk, yaitu sebesar $28,13 \%$, lalu pada tahun 2010 dan 2011 tingkat profitabilitas (return on equity) yang tinggi dimiliki oleh PT. Delta Jakarta Tbk yaitu tahun 2010 sebesar 25,28\% dan tahun 2011 yaitu sebesar 26,48\%,

\subsection{Uji Asumsi Klasik}

\section{- Uji Normalitas}

Uji normalitas ini digunakan untuk menguji apakah dalam sebuah model regresi, variabel dependen, variabel independen, atau kedua - duanya mempunyai distribusi normal atau tidak.

Uji statistik yang digunakan adalah uji statistik non parametic KolmogorovSmirnov (K-S) dengan membuat hipotesis :

$\mathrm{HO}$ : data residual berdistribusi normal dengan signifikasi > dari 0,05.

Ha : data residual tidak berdistribusi normal dengan signifikasi $<$ dari 0,05 .

Tabel 4.12

Hasil Uji Normalitas

\begin{tabular}{|ll|r|r|r|}
\hline & & $\begin{array}{c}\text { WorkingCapitalT } \\
\text { urnover }\end{array}$ & DebttoEquity & $\begin{array}{r}\text { Retuenon } \\
\text { Equity }\end{array}$ \\
\hline$N$ & 36 & 36 & 36 \\
Normal Parametersa..b & Mean & 30.7686 & 29.6725 & 37.6289 \\
& Std. Deviation & 26.17273 & 26.08675 & 29.86259 \\
Most Extreme Differences & Absolute & .163 & .173 & .108 \\
& Positive & .163 & .173 & .108 \\
& Negative & -.127 & -.124 & -101 \\
Kolmogorov-Smirnov Z & & .977 & 1.035 & .647 \\
Asymp. Sig. (2-tailed) & & .296 & .234 & .797 \\
\hline
\end{tabular}

Berdasarkan tabel di atas, dapat diketahui bahwa besarnya nilai Kolmogorov - Smirnov return on equity pada nilai (K-S) sebesar 0,647 dan signifikasi sebesar 0,797. Dari data di atas dapat disimpulkan bahwa perhitungan (K-S) menunjukan data dalam regresi berdistribusi normal dimana nilai signifikasinya $0,797>0,05$. Dan debt to equity dengan nilai signifikasinya $0,234>$ 0,05 menunjukan bahwa berditribusi normal karena $>0,05$. Serta working capital turn over dengan nilai signifikasinya 0,296 > 0,05 berdistribusi normal.

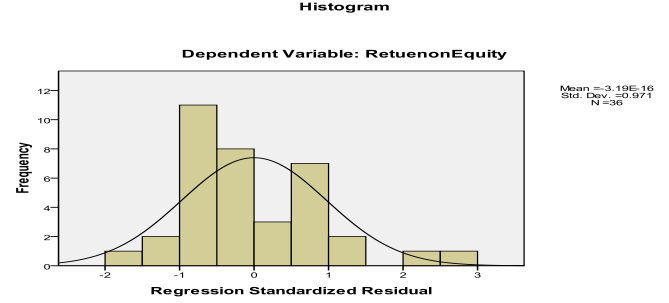


Gambar 4.1

Grafik Histogram Uji Normalitas

Normal P-P Plot of Regression Standardized
Residual

Dependent Variable: RetuenonEquity

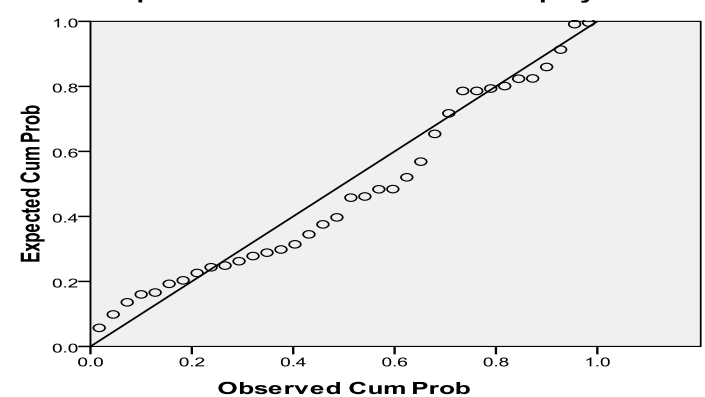

Gambar 4.2

Grafik P-plot Uji Normalitas

Berdasarkan hasil grafik histogram dan dan grafik P-plot di atas, dapat disimpulkan bahwa data memenuhi asumsi normalitas, hal ini dapat dilihat dari grafik histogram yang simetris dan memiliki nilai tengah yang jelas. Selain itu, grafik P-plot menunjukan data menyebar disekitar garis diagonal dan penyebarannya mengikuti garis diagonal, sehingga model regresi ini menunjukan berdistribusi normal.

\section{- Uji Auto Korelasi}

Tabel 4.13

Hasil Durbin Watson

Model Summary ${ }^{b}$

\begin{tabular}{|c|c|c|c|c|c|}
\hline $\begin{array}{l}\text { Mod } \\
1\end{array}$ & $\mathrm{R}$ & $\begin{array}{c}\mathrm{R} \\
\text { Squar } \\
\mathrm{e}\end{array}$ & $\begin{array}{c}\text { Adjuste } \\
\text { d R } \\
\text { Square }\end{array}$ & $\begin{array}{l}\text { Std. } \\
\text { Error of } \\
\text { the } \\
\text { Estimat } \\
\mathrm{e}\end{array}$ & $\begin{array}{c}\text { Durbin } \\
- \\
\text { Watso } \\
n\end{array}$ \\
\hline 1 & .497 & .24 & .201 & 26.6945 & 1. \\
\hline
\end{tabular}

Dari hasil olah data di atas, ditemukan Durbin-Watson sebesar 1,328 dan DW $\geq$ $2 \mathrm{DW} \leq 2$ Maka disimpulkan bahwa data di atas tidak terjadi autokorelasi. Dengan demikian Ho diterima dan $\mathrm{Ha}$ di tolak, sehingga dapat disimpulkan tidak terjadi autokorelasi di antara data pengamatan.

\section{- Uji Heterokedastisitas}

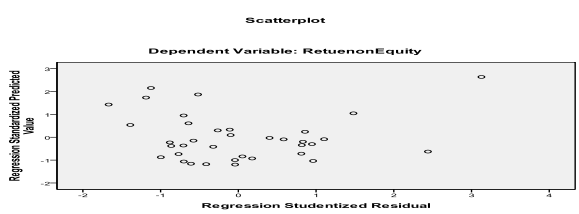

Gambar 4.3

Grafik Scatterplot Uji Heterokedstisitas

Grafik scaterplot di atas terletak bahwa titik-titik menyebar secara acak serta tersebar baik diatas maupun di bawah 0 pada sumbu Y, mengartikan bahwa model regresi telah lolos dari kedua point dasar pengambilan keputusan diatas. Hal ini dapat dikatakan bahwa tidak terjadi heterokedastisitas pada model regresi, yang berarti terjadi kesamaan varians dasar residual suatu pengamatan ke pengamatan lain, atau dengan kata lain model ini telah terjadi homoskedastisitas, yang artinya model tersebut baik digunakan pada penelitian ini.

\section{- Uji Multikolinieritas}

Tabel 4.14

Hasil Uji Multikolinieritas Berdasarkan Nilai Tolerance dan VIF Coefficients $^{\mathrm{a}}$

\begin{tabular}{|l|r|l|}
\hline \multirow{2}{*}{ Model } & \multicolumn{2}{|c|}{$\begin{array}{c}\text { Collinearity } \\
\text { Statistics }\end{array}$} \\
\cline { 2 - 3 } & Tolerance & VIF \\
\hline 1 (Constant) & & \\
WorkingCapitalTurnover & .828 & 1.207 \\
DebttoEquity & .828 & 1.207 \\
\hline
\end{tabular}

a. Dependent Variable: RetuenonEquity

Berdasarkan tabel diatas didapat nilai tolerance dan VIF, dimana terlihat bahwa angka tolerance dan VIF pada variabel working capital turn over dan debt to equity sebesar 0,828 dan 1,207 (nilai VIF berada di antara angka 1 sampai dengan 10) dengan demikian dapat disimpulkan bahwa berdasarkan angka tolerance dan VIF, model 
regresi untuk dua variabel bebas tersebut tidak terjadi multikolinearitas. Artinya antara variabel working capital turn over dan debt to equity tidak terjadi kemiripan yang mengakibatkan korelasi yang sangat kuat antar keduanya. Sehingga terhindar dari pengambilan keputusan mengenai pengaruh pada uji parsial masing - masing variabel independen terhadap variabel dependen.

Tabel 4.15

Hasil Uji Multikolinieritas Berdasarkan Condition Index

Collinearity Diagnostics ${ }^{a}$

\begin{tabular}{|c|c|c|c|c|c|c|}
\hline \multirow[b]{2}{*}{$\begin{array}{l}\text { Mo } \\
\text { del }\end{array}$} & \multirow[b]{2}{*}{$\begin{array}{l}\text { Di } \\
\text { me } \\
\text { nsi } \\
\text { on }\end{array}$} & \multirow[b]{2}{*}{$\begin{array}{l}\text { Eigen } \\
\text { value }\end{array}$} & \multirow[b]{2}{*}{$\begin{array}{l}\text { Conditi } \\
\text { on } \\
\text { Index }\end{array}$} & \multicolumn{3}{|c|}{ Variance Proportions } \\
\hline & & & & $\begin{array}{c}(\text { Cons } \\
\tan t)\end{array}$ & $\begin{array}{c}\text { Workin } \\
\text { gCapita } \\
\text { lTurno } \\
\text { ver }\end{array}$ & $\begin{array}{l}\text { Debtto } \\
\text { Equity }\end{array}$ \\
\hline 1 & 1 & 2.517 & 1.000 & .05 & .05 & .05 \\
\hline & 2 & .249 & 3.176 & .16 & .29 & .95 \\
\hline & 3 & .234 & 3.282 & .79 & .66 & .01 \\
\hline
\end{tabular}

a. Dependent Variable: RetuenonEquity

Berdasarkan table di atas nilai condition index yang dihasilkan oleh variabel independent kurang dari 30, maka dapat disimpulkan bahwa variabel independen tidak terjadi multikolonieritas.

\subsection{Uji Regresi}

Tabel 4.16

Hasil Uji Regresi

Coefficients $^{\mathrm{a}}$

\begin{tabular}{|c|c|c|c|c|c|}
\hline \multirow[b]{2}{*}{ Model } & \multicolumn{2}{|c|}{$\begin{array}{l}\text { Unstandar } \\
\text { dized } \\
\text { Coefficien } \\
\text { ts }\end{array}$} & $\begin{array}{c}\text { Standar } \\
\text { dized } \\
\text { Coeffic } \\
\text { ients }\end{array}$ & & \\
\hline & B & $\begin{array}{c}\text { Std. } \\
\text { Error }\end{array}$ & Beta & $\mathrm{t}$ & g. \\
\hline 1 (Constant) & $\begin{array}{r}17 . \\
318\end{array}$ & 7.637 & & $\begin{array}{r}2.2 \\
68\end{array}$ & $\begin{array}{r}.0 \\
30\end{array}$ \\
\hline WorkingCapita & .39 & .189 & .348 & 2.0 & .0 \\
\hline lTurnover & 7 & & & 95 & 44 \\
\hline DebttoEquity & $\begin{array}{r}.27 \\
3\end{array}$ & .190 & .239 & $\begin{array}{r}1.4 \\
37\end{array}$ & $\begin{array}{l}.1 \\
60\end{array} \mid$ \\
\hline
\end{tabular}

a. Dependent Variable: RetuenonEquity

Berdasarkan hasil pengolahan data pada tabel diperoleh persamaan regresi sebagai berikut:
$Y=17,318+0,397 X_{1}+0,273 X_{2}$

Koefisien dari masing-masing variabel tersebut dapat di interpretasikan sebagai berikut :

1. Koefisien X1 working capital turn over sebesar 0,397, artinya jika working capital turn over naik sebesar satu satuan, maka tingkat return on equity akan meningkat sebesar 0,397.

2. Koefisien X2 debt to equity sebesar 0,273 , artinya jika debt to equity naik sebesar satu satuan, maka tingkat return on equity akan meningkat sebesar 0,273.

3. Konstanta sebesar 17,318 mempunyai arti : jika tidak ada kenaikan working capital turn over dan debt to equity, maka tingkat return on equity sebesar 17,318 .

\subsection{Uji Koefisen Determinasi}

Untuk mengetahui pengaruh variabel $\mathrm{X}_{1}$ kenaikan efisiensi modal kerja (working capital turn over) dan variabel $\mathrm{X}_{2}$ debt to equity terhadap $\mathrm{Y}$ profitabilitas (return on equity), dilakukan perhitungan koefisien determinasi dengan rumus sebagai berikut:

Tabel 4.16

Hasil Uji Koefisien Determinasi Model Summary ${ }^{b}$

\begin{tabular}{|c|c|c|c|c|c|}
\hline $\begin{array}{c}\text { Mode } \\
1\end{array}$ & $\mathrm{R}$ & $\begin{array}{c}\mathrm{R} \\
\text { Squar } \\
\mathrm{e}\end{array}$ & $\begin{array}{c}\text { Adjuste } \\
\text { d R } \\
\text { Square }\end{array}$ & \begin{tabular}{|c|} 
Std. \\
Error of \\
the \\
Estimat \\
$\mathrm{e}$
\end{tabular} & $\begin{array}{c}\text { Durbin } \\
- \\
\text { Watso } \\
n\end{array}$ \\
\hline 1 & $\begin{array}{r}497 \\
\mathrm{a}\end{array}$ & .247 & .201 & $\begin{array}{r}26.6945 \\
7\end{array}$ & 1.328 \\
\hline
\end{tabular}

$$
\mathrm{Kd}=\mathbf{r}^{2} \times 100 \%
$$

Berdasarkan perhitungan koefisien determinasi, diketahui bahwa nilai $\mathrm{Kd}=$ 24,7\%. Maka dapat disimpulkan bahwa pengaruh working capital turn over dan variabel debt to equity terhadap return on 
equity termasuk kriteria lemah. Serta korelasi antara working capital turn over dan debt to equity secara bersama - sama dapat mempengaruhi return on equity sebesar $24,7 \%$ sedangkan sisanya $75,3 \%$ dipengaruhi oleh faktor lain yang tidak ditelilti pada penelitian ini.

\subsection{Uji F}

Tabel 4.17

Hasil Uji F

ANOVA $^{b}$

\begin{tabular}{|l|r|r|r|r|r|}
\hline \multicolumn{1}{|l|}{ Model } & $\begin{array}{r}\text { Sum of } \\
\text { Squares }\end{array}$ & df & $\begin{array}{c}\text { Mean } \\
\text { Square }\end{array}$ & F & Sig. \\
\hline $1 \quad$ Regre & 7696.3 & 2 & 3848.15 & 5.40 & $.009^{\mathrm{a}}$ \\
01 & & 1 & 0 & \\
Ssion & 23515. & 33 & 712.600 & & \\
Resid & 806 & & & & \\
ual & & & & \\
Total & $\begin{array}{r}31212 . \\
107\end{array}$ & 35 & & & \\
\hline
\end{tabular}

Kriteria pengujian dengan taraf signifikan $\alpha=0,05$ atau 36-2-1 $=33$ diperoleh $\mathrm{F}^{\text {tabel }}$ sebesar 3,284918. Dengan menggunakan program Ms Excel dengan rumus $=\operatorname{FINV}(0,05 ; 2 ; 33)$ diperoleh $F_{\text {tabel }}$ 3,284918. Berdasarkan tabel diatas dapat dilihat: $F_{\text {hitung }}$ pada tabel ANOVA adalah 5,400 sedangkan $F_{\text {tabel }}(\alpha=0,05)$ adalah 3,284918. Jadi, $F_{\text {hitung }}>F_{\text {tabel }}$ yang berarti Ho ditolak Ha diterima. Untuk itu, dapat dikatakan bahwa variabel working capital turn over dan debt to equity berpengaruh signifikan terhadap variabel return on equity.

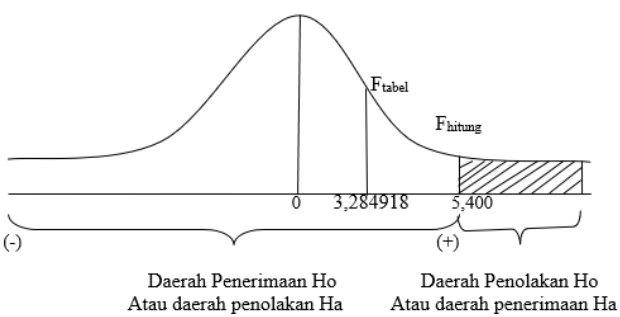

Gambar 4.4

Kurva Penerimaan dan Penolakan Hipotesis Uji F

Dari gambar di atas, diketahui bahwa $\mathrm{F}_{\text {hitung }}>\mathrm{F}_{\text {tabel }}$, Ho ditolak Ha diterima.

\subsection{Uji t}

Tabel 4.18

Hasil Uji t Coefficients ${ }^{a}$

\begin{tabular}{|c|c|c|c|c|c|}
\hline \multirow[b]{2}{*}{ Model } & \multicolumn{2}{|c|}{$\begin{array}{c}\text { Unstandard } \\
\text { ized } \\
\text { Coefficient } \\
\text { s }\end{array}$} & \multirow{2}{*}{\begin{tabular}{|c|}
$\begin{array}{c}\text { Standard } \\
\text { ized } \\
\text { Coeffici } \\
\text { ents }\end{array}$ \\
Beta
\end{tabular}} & \multirow[b]{2}{*}{$\mathrm{t}$} & \\
\hline & B & $\begin{array}{l}\text { Std. } \\
\text { Error }\end{array}$ & & & \\
\hline 1 (Constant) & $\begin{array}{r}17.3 \\
18\end{array}$ & 7.637 & & $\begin{array}{r}2.2 \\
68\end{array}$ & \\
\hline $\begin{array}{l}\text { WorkingCapital } \\
\text { Turnover }\end{array}$ & .397 & .189 & .348 & $\begin{array}{r}2.0 \\
95\end{array}$ & \\
\hline DebttoEquity & .273 & .190 & .239 & $\begin{array}{r}1.4 \\
37\end{array}$ & \\
\hline
\end{tabular}

Kriteria pengujian dengan taraf signifikan $\alpha=0,05$ atau 36-2-1 = 33 dengan menggunakan program Ms Excel dengan rumus $=\operatorname{TINV}(0,05 ; 33)$ diperoleh $t_{\text {tabel }}$ 2,0345153. Bahwa $t_{\text {hitung }} 2,095>t_{\text {tabel }}$ 2,0345153 jadi hipotesis Ho ditolak Ha diterima yang berarti tidak berpengaruh signifikan antara working capital turn over terhadap return on equity secara parsial.

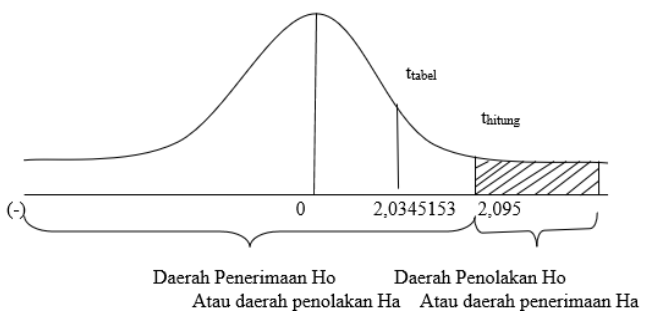

Gambar 4.5

Kurva Penerimaan dan Penolakan Working Capital Turnover 
1. Bahwa $t_{\text {hitung }} 1,437<t_{\text {tabel }} 2,0345153$ jadi hipotesis Ho diterima Ha ditolak yang berarti tidak pengaruh signifikan antara debt to equity terhadap profitabilitas (return on equity) secara parsial

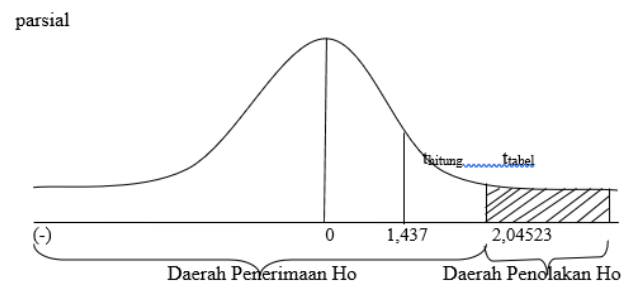

Dari gambar diatas, dapat disimpulkan bahwa untuk working capital turn over $\mathrm{t}_{\text {hitung }}$ dan debt to equity $\mathrm{t}_{\text {hitung }}<\mathrm{t}_{\text {tabel }}$ maka Ho diterima dan Ha ditolak.

\section{Gambar 4.6}

Kurva Penerimaan dan Penolakan Debt to Equity

\section{Pembahasan}

Penelitian ini merupakan studi mengenai laporan posisi keuangan yang dikeluarkan oleh perusahaan. Didalam laporan tersebut terdapat informasi mengenai data - data yang diperlukan dalam penelitian karya ilmiah ini dan dari data data tersebut mengahasilkan nilai rasio. Berdasarkan rasio - rasio tersebut dapat dilihat pengaruh efisiensi modal kerja (working capital turn over), debt to equity dan profitabilitas (return on equity) pada perusahaan manufaktur food and bevereges yang terdaftar di BEI.

Analisi regresi berganda diperoleh $\mathrm{Y}=$ $17,318+0,397 X_{1}+0,273 X_{2}$ dapat dijelaskan bahwa jika tidak ada working capital turn over, dan debt to equity maka nilai return on equity sebesar. 17,318\%. Setiap peningkatan variabel working capital turn over sebesar satu satuan maka akan kenaikan return on equity sebesar 0,397\% dan setiap penurunan variabel debt to equity sebesar satu satuan maka akan menaikan return on equity sebesar $0,273 \%$.

Berdasarkan perhitungan koefisien determinasi, diketahui bahwa nilai $\mathrm{Kd}=$ $24,7 \%$. Maka dapat disimpulkan bahwa pengaruh working capital turn over, debt to equity terhadap return on equity pada perusahaan manufaktur food and bevereges yang terdaftar di BEI termasuk ke dalam kurang kuat. Serta korelasi antara working capital turn over dan debt to equity secara bersama-sama dapat mempengaruhi return on equity sebesar $24,7 \%$ sedangkan sisanya sebesar 75,3\% dipengaruhi oleh faktor lain yang tidak ditelilti pada penelitian ini.

Selanjutnya, hasil penelitian secara parsial menunjukan bahwa working capital turn over berpengaruh positif dan signifikan terhadap tingkat return on equity, dengan nilai $t_{\text {hitung }} 2,095>t_{\text {tabel }} 2,0345153$ dan nilai signifikan kurang dari 0,05 yaitu sebesar 0,044 berbedadengan Syaiful Arif (2015) Variabel Working Capital Turnover (WCT) (X1) memiliki $t_{\text {hitung }}$ sebesar $-0,092$ $<\mathrm{t}_{\text {tabel }} 2.032244$ dengan signifikansi 0,928 $>0,05$ maka H0 diterima dan Ha ditolak, artinya variabel WCT (X1) tidak memiliki pengaruh positif dan signifikan secara parsial terhadap ROE (Y2).

Dan debt to equity tidak perpengaruh signifikan terhadap return on equity, dengan nilai $t_{\text {hitung }} 1,437<t_{\text {tabel }} 2,0345153$ dan nilai signifikan lebih besar dari 0,05 yaitu sebesar 0,160 . berbeda dengan Hartono (2015) Hasil uji secara parsial (ujit) variabel debt to equity ratio menunjukkan nilai t hitung sebesar -4.312 dan signifikan sebesar 0.000 , maka $t_{\text {hitung }}<t_{\text {tabel }}(-4.312<$ $2.015368)$ dan nilai signifikan $(0.000<$ 0.05 ) sehingga secara parsial debt to equity ratio berpengaruh negative dan signifikan terhadap return on equity pada perusahaan manufaktur subsektor logam dan sejenisnya, sedangkan menurut penelitian Syaiful Arif (2015) variabel Debt to Equity Ratio (DER) (X3) memiliki thitung sebesar $8,052<t_{\text {tabel }} 2.032244$ dengan signifikansi $0,000<$ dari 0,05 maka Ha diterima dan $\mathrm{H} 0$ ditolak, artinya variabel DER (X3) berpengaruh negative namun signifikan terhadap ROE (Y2).

Dan untuk analisis secara simultan, menunjukan bahwa working capital turn over, dan debt to equity berpengaruh positif dan signifikan terhadap tingkat return on equity dengan nilai, $\mathrm{F}_{\text {hitung }}\left\langle\mathrm{F}_{\text {tabel }}(5,400\rangle\right.$ $3,284918)$ dengan nilai signifikan kurang dari 0,05 yaitu sebesar 0,009 .

\section{Simpulan}


Dari hasil pengujian hipotesis penelitian dan pengujian regresi sederhana, dapat diperoleh kesimpulan:

1. Pengaruh working capital turn over dan debt to equity return on equity pada perusahaan - perusahaan yang terdaftar di BEI bergerak dalam bidang Food and Bavereges periode 2009 - 2013 berpengaruh positif dan signifikan dengan nilai $\mathrm{F}_{\text {hitung }}>\mathrm{F}_{\text {tabel, }}$ yaitu $(5,400<$ 3.284918) dan nilai signifikan lebih kecil dari 0,05 yaitu sebesar 0,009.

2. Pengaruh working capital turn over terhadap return on equity berpengaruh positif dan signifikan dengan nilai $t_{\text {hitung }}$ $2,095>t_{\text {tabel }} 2,0345153$ dengan nilai signifikan lebih kecil dari 0,05 yaitu sebesar 0,044, dan antara debt to equity terhadap return on equity tidak terdapat pengaruh signifikan dengan nilai $t_{\text {hitung }}$ $1,437<\mathrm{t}_{\text {tabel }} 2,0345153$ dengan nilai signifikan lebih besar dri 0,05 yaitu sebesar 0,160.

3. Pengaruh working capital turn over dan debt to equity terhadap return on equity dalam penelitian ini berkriteria lemah, berdasarkan hasil koefisien determinasi yaitu sebesar 0.247 , dan untuk angka $\mathrm{R}$ square sebesar $24,7 \%$ yang diartikan bahwa working capital turn over dan debt to equity memiliki pengaruh sebesar $24,7 \%$ terhadap return on equity dan sisanya $75,3 \%$ dipengaruhi oleh faktor lain yang tidak diteliti dalam penelitian ini.

\section{Saran}

Berdasarkan kesimpulan di atas, maka peneliti mencoba memberikan saran, antara lain adalah :

1. Tingkat perputaran modal kerja harus lebih ditingkatkan lagi karena apabila nilai tingkat perputaran modal kerja tinggi maka dapat dikatakan efisien dalam menggunakan modal kerja, dan tingkatkan penjualan perusahaan agar tingkat perputaran modal kerja lebih cepat.

2. Perusahaan harus lebih produktif menggunakan modal kerja, agar modal kerja yang diinvestasikan tidak ada yang sia - sia.

3. Jumlah modal kerja harus dikendalikan, agar sesuai dengan porsi yang dibutuhkan perusahaan.

\section{DAFTAR PUSTAKA}

Baridwan Zaki. 2011. Intermediate Accounting. Yogyakarta: BPFE

Bringaham Eugene F, Houston Joel F. 2010. Dasar - Dasar Manajemen Keuangan. Jakarta: Salemba Empat.

Dewan Standar Akuntansi Indonesia. 2015. PSAK 2015. Graha Akuntan

Fahmi Irham. 2015. Analisis Laporan Keuangan. Bandung: Alfabeta

Husnan Suad, Pudjiastuti Enny. 2012. Dasar - Dasar Manajemen Keuangan. Yogyakarta: UPP STIM YKPN

Jumingan. 2014. Analisis Laporan Keuangan. Jakarta: BumiAksara Munawir. 2010. Analisis Laporan Keuangan. Yogyakarta: Liberty Kasmir. 2011. Analisa Laporan Keuangan. Jakarta: PT. Raja Grafindo Persada.

Riyanto Bambang. 2010. Dasar-Dasar Pembelanjaan Perusahaan.

Yogyakarta:BPFE

Sartono Agus. 2010. Manajemen Keuangan Teori dan Aplikasi. Yogyakarta: BPFE

Sofya Safri Harahap. 2013. Analisis Kritis Atas Laporan Keuangan, Jakarta: Rajagrafindo Persada.

Sugiyono. 2012. Metode Penelitian Bisnis. Bandung: Alfabeta.

Sunyoto Danang. 2012. Analisis Regresi dan Uji Hipotesis. Yogyakarta: CAPS

Arif Syaiful . 2015. Pengaruh Perputaran Modal Kerja, Leverage Dan Pertumbuhan Penjualan Terhadap Profitabilitas Studi Pada Perusahaan Makanan Dan Minuman Yang Terdaftar Di Bursa Efek Indonesia Pada Tahun 2011-2013. Universitas Brawijaya. Malang.

Hantono. 2015. Pengaruh Current Ratio dan Debt to Equity Ratio terhadap Profitabilitas Pada Perusahaan Manufaktur Sektor Logam dan Sejenisnya yang Terdaftar Di Bursa Efek Indonesia Periode 2009-2013. Universitas Prima Indonesia. Medan. 
Wibowo Agus, 2012. Efisiensi Modal Kerja, Likuiditas Dan Leverage Terhadap Profitabilitas Pada Perusahaan Manufaktur Di BEI. Universitas Negeri Semarang, Indonesia

Yulianti Dwi Lestari. 2011. Analisis Pengaruh Efisiensi Modal Kerja, Likuiditas, Dan Solvabilitas Terhadap Profitabilitas Perusahaan Studi Empiris Pada Perusahaan Manufaktur Yang Listed Di Bursa Efek Indonesia. Universitas Jember. Jember. 
